The Brazilian Empire in the Nineteenth Century. National Slavery, Planter Class and Intellectuals in the Process of State Building

\title{
0 Império do Brasil no contexto do século XIX. Escravidão nacional, classe senhorial e intelectuais na formação do Estado ${ }^{1}$
}

\section{Ricardo Henrique Salles \\ Professor da Escola de História da Universidade Federal do Estado do Rio de Janeiro (UNIRIO - Rio de Janeiro / Brasil), pesquisador do Conselho Nacional de Desenvolvimento Científico e Tecnológico (CNPq) e de seu Programa de Núcleos de Excelência (Pronex), "Dimensões e fronteiras do Estado brasileiro no século XIX" (2010-2012). \\ e-mail: ricardohsalles@gmail.com}

\section{Resumo}

0 ensaio analisa as relações entre a formação do Estado nacional brasileiro, no período entre 1847 e 1889, e a formação e desenvolvimento históricos da classe senhorial nucleada em torno da Bacia do rio Paraíba do Sul. Para efetuar esta análise, lança mão de categorias gramscianas, tais como intelectuais, classe nacional, hegemonia, e situa a experiência histórica do Império do Brasil com outras experiências similares do século XIX, particularmente aquela da Itália.

\section{Abstract \\ This essay refers to the relationship between the national State building process in Brazil, from 1847 to 1889, and the formation of the planter class in the Basin of the Paraiba do Sul river. Gramscian categories, such as intellectuals, national class and hegemony, will be used to perform the analysis. The Brazilian historical experience will also be considered in light of other national experiences, notably the Italian State building process.}

Palavras-chave

Império do Brasil, escravidão, Estado nacional, século XIX

Keywords

Brazilian Empire, Slavery, National State, Nineteenth century
Diferentes versões deste texto foram apresentadas no II Simpósio de História do Maranhão Oitocentista, em São Luís, no dia 7 de junho de 2011; no Seminário interno do Pronex "Dimensões e fronteiras do Estado brasileiro no século XIX", em Teresópolis, nos dias 3 e 4 de outubro de 2011, e no Fórum da Revista Almanack, realizado no Rio de Janeiro, em 3 de novembro do mesmo ano. Agradeço aos organizadores desses eventos e a todos que se dispuseram ao debate nestas ocasiões, especialmente a Carlos Gabriel Guimarães e Maria Fernanda Vieira Martins, meus debatedores do Fórum. Agradeço, ainda, a leitura atenta e os comentários de Rafael Marquese, Keila Grinberg e Mariana Muaze. 
2

Não me deterei aqui sobre esse aspecto. Remeto ao trabalho de Keila Grinberg, 0 fiador dos brasileiros. Cidadania, escravidâo e direitos civis nos tempos de Rebouças. Rio de Janeiro: Civilização Brasileira, 2002, que analisa o assunto tomando por base a trajetória de Antônio Pereira Rebouças (1798-1880), homem de cor baiano, filho de uma liberta e um alfaiate português que fez carreira politica em sua provincia, adquirindo relativa projeção no cenário nacional.

3

SALLES, Ricardo. E o Vale era o escravo. Vassouras, século XIX: senhores e escravos no Coração do Império. Rio de Janeiro: Civilização Brasileira, 2008. p.77-134.
Nesse ensaio discutirei a relação entre a classe senhorial, considerada como uma formação histórica particular de grandes proprietários rurais escravistas, nucleada em torno da zona cafeeira da Bacia do Rio Paraiba do Sul na província do Rio de Janeiro, envolvendo regiões das províncias de Minas Gerais, São Paulo e a Corte. Entenderei a classe senhorial como uma classe nacional - expressão tomada de Antonio Gramsci - não no sentido de que ocupasse todo o território nacional e nele se configurasse de forma homogênea, mas no sentido de que sua dominação foi nacional, organizada a partir do Estado, submetendo e incorporando interesses de outros grupos e classes sociais, tanto da sua quanto de outras regiões do Império. Dizer que a classe senhorial foi uma classe nacional significa ainda que sua dominação aconteceu a partir da afirmação de uma ordem social e econômica em que a escravidão foi o denominador comum, mais para uns, menos para outros, que soldou esse processo de dominação e incorporação nacionais.

Dessa ordem estavam excluídos os escravos, para quem era reservada a submissão pela força. Parcialmente excluídos estavam também os libertos, os homens e mulheres, brancos, negros e pardos, livres, desprovidos da plenitude dos direitos políticos e submetidos a modos informais, mas nem por isso menos efetivos, de dominação. Esse sistema de dominação, contudo, não era desprovido de concessões - entre elas, inclusive a prática difundida, mas seletiva, da alforria - e elasticidade que marcavam as relações sociais de força entre senhores e escravos diretamente e entre os primeiros e grupos sociais livres na base da pirâmide social, indiretamente. Os descendentes de libertos gozavam de plenos direitos formais de cidadania e alguns poucos chegaram a ter papel de destaque relativo. ${ }^{2}$

A transformação de um grupo social de base regional de senhores de escravos em uma classe dominante nacional não foi um processo espontâneo, mas uma construção histórica. Além de uma série de condições econômicas, sociais e culturais objetivas, das práticas moleculares e difundidas entre os principais integrantes dessa classe, no território e no tempo, demandou a ação concreta e específica de uma camada de intelectuais que, em um determinado período de tempo, grosso modo identificado com o advento, o apogeu e a queda do Segundo Reinado, entre 1840 e 1889, se colocou à frente e dirigiu esse processo. Essa camada aglutinou-se em torno do serviço ao Estado, e se formou a partir de diferentes origens sociais, normalmente, mas não exclusivamente, entre os setores dominantes. Provinha de distintas regiões do país, e não apenas da área de nucleação da classe senhorial na Bacia do Paraiba. Apesar de sua origem diversificada e de sua autonomia, dada pelas formas de sociabilidade da carreira política, ela sempre gravitou em torno da região da Bacia do Paraíba e de seus grandes proprietários rurais escravistas. Sua atuação, enquanto um grupo de estadistas, sempre levou em conta os interesses e os anseios dessa região e dessa classe. Mesmo quando tal atuação entrou em conflito com outros grupos, mais diretamente ligados aos interesses locais e corporativos desses grandes proprietários, como aconteceu quando da votação da lei de 28 de setembro de 1871, que decretava a liberdade do ventre da mulher escrava. ${ }^{3}$ Esse momento crítico de disjunção entre a atuação predominante do grupo de estadistas e os representantes mais diretos dos fazendeiros foi, em seguida, recomposto. Sobre novas bases jurídico-políticas, estabelecidas a partir de 1871, a atuação dos estadistas imperiais, principalmente no que diz respeito ao partido conservador, continuou a se pautar pela defesa dos interesses da classe senhorial. Uma nova, e desta vez definitiva, ruptura 
4

MARTINS, Maria Fernanda Vieira. A velha arte de governar: um estudo sobre política e elites a partir do Conselho de Estado (1842-1889). Rio de Janeiro: Arquivo Nacional, 2007. 0 Conselho de Estado fora criado como órgão consultivo do Poder Executivo pela Constituição de 1824. Seus membros eram escolhidos pelo imperador $e$ tinham assento vitalício no Conselho. 0 primeiro Conselho funcionou de 1824 a 1834, quando ele foi extinto pelo Ato Adicional à Constituição aprovado nesse mesmo ano pela Assembleia. Essa extinção foi revogada em 1842, já na vigência do Segundo Reinado.

5

CARVALHO, José Murilo de. A construção da ordem e 0 teatro de sombras. Rio de Janeiro: Civilização Brasileira, 2006. Citarei também a edição de 1996 de $A$ construção da ordem e Teatro de sombras. Rio de Janeiro: Relume Dumará, 1996.

6

Ibidem, 1996, p.229.

7

HOLANDA, Sérgio Buarque de. Do Império à República. In: Idem (org.). História geral da civilização brasileira. Império. 5 vols. Tomo II. São Paulo: Difel, 1985.

8

DOLHNIKOFF, Miriam. 0 pacto imperial: origens do federalismo no Brasil do século XIX. São Paulo: Globo, 2005. só veio a ocorrer em 1888 com a abolição da escravidão. Nesse sentido, o grupo de estadistas imperiais, particularmente em seu corte conservador, constitui-se em uma camada de intelectuais, isto é de dirigentes políticos, morais e intelectuais, da classe senhorial.

Essas colocações, que serão retomadas e desenvolvidas ao longo do texto, alinham-se a uma concepção geral sobre a formação do Estado imperial que o considera enquanto elemento de poder de classe. Na explanação dessa concepção, dialogarei com quatro vertentes de interpretação sobre a natureza do Estado e do poder imperiais: 1) a vertente do patrimonialismo e do clientelismo, atualizada em sua versão das redes familiares de interesse; 2) a vertente da elite política imperial; 3) a vertente das elites regionais, dispersa pela historiografia atual, e expressa na tese da dominação tetrárquica das grandes províncias de Minas Gerais, Bahia, Pernambuco e Rio de Janeiro, de Sérgio Buarque de Holanda; 4) a vertente da classe senhorial, como exposta por Ilmar Rohloff de Mattos.

Resumidamente, a primeira vertente, ainda que a autora não assuma essa imputação, é expressa na análise de Maria Fernanda Vieira Martins sobre o segundo Conselho de Estado (1842-1889). ${ }^{4}$ Segundo sua análise, 0 funcionamento do Conselho, reconhecido como um órgão essencial na configuração do poder imperial, remeteria a práticas governativas do Conselho de Estado monárquico do Antigo Regime português. Essas práticas governativas seriam mais ou menos atualizadas no caso da monarquia brasileira a partir de uma demanda imposta pelas necessidades de modernização política, características das práticas e culturas políticas presentes na construção dos Estados nacionais do século XIX. Nesse contexto, a elite dos conselheiros de Estado imperiais governaria fundamentalmente a partir de interesses próprios, tecidos em suas redes sociais de interesse de família e compadrio. A tese da elite política imperial, expressa por José Murilo de Carvalho, é sobejamente conhecida. 0 Estado imperial seria governado por uma elite política, dotada de unidade e coesão internas, dadas por sua formação e treinamento comuns, portadora de um projeto próprio de construção de um Estado nacional. Essa elite, autônoma em relação à classe dominante formada pelos grandes proprietários de terras e de escravos, manteria com essa classe relações de conflito e aliança caracterizadas por uma "dialética da ambiguidade". $\mathrm{A}$ partir do regresso conservador de 1837, depois de um período de acumulação primitiva de poder, realizado pela elite política de origem coimbrã e pela elite política brasileira em formação, teria se esboçado um sistema de dominação política "mais sólido, centrado na aliança entre, de um lado o rei e a alta magistratura, e, de outro, o grande comércio e a grande propriedade, sobretudo a cafeicultura fluminense". 6

A terceira vertente, das elites regionais, aqui expressa por Sérgio Buarque de Holanda, é a de que as principais províncias em termos de representação política, Minas Gerais, Bahia, Rio de Janeiro e Pernambuco, exerceriam uma "dominação tetrárquica". Entre elas, a Bahia teria um papel de destaque, tendo estado à frente de $1 / 3$ dos gabinetes imperiais, podendo-se mesmo falar de um "baianismo" característico da política do Segundo Reinado. ${ }^{7}$ Recentemente, Miriam Dolhnikoff, opondo-se às teses de uma elite centralizada e do poder da classe senhorial, salientou o papel das elites regionais, que teriam assegurado seu poder específico num pacto imperial com o governo central. Tal pacto estaria nas origens do federalismo no país. ${ }^{8}$

A quarta vertente, do Estado imperial entendido como dimensão do poder de uma classe senhorial nucleada em torno dos grandes proprietários 
9

MATTOS, IImar R. de. 0 tempo saquarema. São Paulo: Hucitec, 1987. Há outras interpretações importantes que, de meu ponto de vista, remetem a estas quatro vertentes. Como exemplos mais expressivos, podem ser citados o trabalho de Fernando Uricoechea, que vê no Estado imperial um processo de burocratização que se desdobra sobre uma base clientelar e patrimonialista (URICOECHEA, Fernando. O minotauro imperial. A burocratização do Estado imperial. São Paulo: Difel, 1976); o trabalho de Richard Graham, que efetua a mesma discussão buscando combinar os dois processos, de centralização e patronagem (GRAHAM, Richard. Clientelismo e política no Brasil do século XIX. Rio de Janeiro: UFRJ, 1999); e o livro de Jeffrey Needell, que identifica uma ligação intima entre a elite política saquarema e os grandes proprietários rurais fluminenses num primeiro momento, até o ministério do marquês de Paraná, para depois indicar um crescente conflito entre os saquaremas e a vontade do imperador e de outros membros da elite política a ele aderidos (NEEDELL, Jeffrey. The Party of Order. The Conservatives, the State, and Slavery in the Brazilian Monarchy, 1831-1871. Stanford: Stanford University Press, 2006).

10

Sobre a criação do cargo de Presidente do Conselho de Ministros, ver BARBOSA, Silvana M. 0 Conselho de Ministros no Império do Brasil. In: Locus, Juiz de Fora, v.13, p. 53-64, 2007. Os termos liberais e conservadores, assim como partido, são empregados aqui para designar os grupos políticos cujas trajetórias, tanto em termos de proposições quanto de pessoas, aproximadamente, podem ser identificadas com a formação das duas grandes tendências que dominaram a vida politica do Império e que já estavam consolidados como tais em 1847, marco inicial desse trabalho. Portanto, podem indicar, dependendo do momento empregado, entidades concretas - os partidos liberal e conservador em 1875 - ou tendências somente identificáveis a posteriori - liberais e conservadores em 1838, por exemplo.

11

LYRA FILHO, João. Visconde de Itaboraí. A luneta do Império. SI: se, sd, p.16 e ss.

12

SOUZA, José Antonio Soares de. A vida do visconde do Uruguai. São Paulo: Companhia Editora Nacional, 1944. p.45. rurais escravistas da província fluminense, representada por Ilmar Rohloff de Mattos, é a perspectiva adotada aqui. Sua exposição e interpretação se dará ao longo do texto. ${ }^{9}$

Quanto ao período abrangido neste ensaio, ele será o do Segundo Reinado. Mais precisamente, entre 1847, ano de criação do cargo de Presidente do Conselho de Ministros, e 1889, ano da queda da monarquia. A definição de tal período, como todo exercício de periodização, carrega em si uma boa dose de escolha e intervenção do historiador sobre um processo histórico que é múltiplo, complexo e aberto, no sentido de que traz em si inúmeras e inesgotáveis possibilidades de desdobramento. Possibilidades estas, no entanto, que não são arbitrariedades impostas pelo historiador e tampouco são infinitas, no sentido de que tudo poderia ter acontecido em um ponto qualquer da História. Na vida, tudo sempre pode acontecer, mas dentro de determinadas circunstâncias e possibilidades delimitadas pelo próprio desenrolar do processo histórico. Isso quer dizer que aqui se assume uma concepção sobre o devir histórico em que, se ele é múltiplo, complexo, aberto, eventual, singular e, nesse sentido, impossível de predizer, não deixa de ser contínuo e cumulativo. 0 que aconteceu antes afeta 0 que vem depois e o que veio depois lança luz sobre o que aconteceu antes.

Trocando em miúdos para a delimitação temporal específica aqui proposta: o ponto final do período, o da queda da monarquia em 1889, não requer maiores explicações. Já o marco inicial de 1847, sim. Este foi o ano da criação do cargo de Presidente do Conselho de Ministros. Esse fato pode ser considerado um dos marcos da estabilização do sistema parlamentar do Império. A partir daí, as regras do jogo ficaram definidas e os partidos, configurados; mais o conservador e menos o liberal. 0 papel do imperador e do poder moderador foi aceito, ou pelo menos tolerado. Tudo isso, por sua vez, foi a expressão do predomínio político de uma facção específica, no interior do partido conservador, o grupo dos saquaremas fluminenses. ${ }^{10}$

0 grupo teve sua alcunha derivada da região em que seus principais líderes, Joaquim José Rodrigues Torres (1802-1872), futuro visconde de Itaboraí, e Paulino José Soares de Sousa (1807-1866), futuro visconde de Uruguai, tinham sua base social e política. Os dois eram casados com filhas de João Álvares de Azevedo, grande proprietário rural na região. "Paulino nasceu em Paris, para onde seu pai, mineiro de Paracatu, emigrara, lá se casando e se formando em medicina. A família se mudou para Portugal em 1814 e, seguida, veio para o Brasil, estabelecendo-se no Maranhão. Em 1823, Paulino foi para Coimbra, onde cursou até o quarto ano do curso de direito, que concluiria em São Paulo, em 1831. Em Coimbra, além de seu tio, primo de seu pai, Bernardo Belisário Soares de Sousa, conviveu e estreitou relações com Honório Hermeto Carneiro Leão. Essas e outras amizades valeram-Ihe um começo de vida profissional favorável. Em 1828, Paulino voltou ao Brasil e estabeleceu-se em São Paulo para completar seus estudos. Em 1832, depois de uma breve estadia na Corte, foi nomeado juiz em São Paulo pelo ministro da Justiça, o padre Feijó, por indicação do regente José da Costa Carvalho. Pouco depois, por indicação de Honório Hermeto, novo ministro da Justiça, transferiu-se definitivamente para o Rio de Janeiro, aproximando-se ainda mais do centro do poder. Em 1833, sua ascensão social e política se completou pelo casamento com Ana Macedo Álvares de Azevedo, cujo pai, segundo seu biógrafo, "tinha parentesco e relações de família com os principais fazendeiros da baixada, que representavam então uma das mais consideráveis forças políticas da província". ${ }^{12}$ 
Seu casamento foi realizado na casa de seu concunhado, Rodrigues Torres, ministro da Marinha.

Rodrigues Torres vinha, ele mesmo, de uma familia de proprietários rurais em Itaboraí. Seu casamento com a outra filha de João Álvares de Azevedo, Maria Álvares Azevedo Macedo, apenas confirmava e fortalecia seus vínculos com o grupo dos grandes proprietários da Baixada. Seu casamento fazia parte de um movimento de sua família que, principalmente através de seu irmão Cândido José Rodrigues Torres, futuro barão Itambi, estendia seus laços de parentesco e alianças junto a capitalistas e fazendeiros da província. Reiterando este movimento, a filha de Cândido, Maria Carolina Soares Torres casou-se com José Antônio Soares Ribeiro, grande proprietário rural na zona de Maricá e futuro barão de Inoã. 0 outro filho de Cândido, Cândido José Rodrigues Torres, mais tarde visconde de Torres, por sua vez, estendeu o movimento em direção a Serra-Acima. Casou-se com Ana Bernardina Teixeira Leite, neta do barão de Itambé, cuja família era uma das principais de Vassouras. Consolidando estes laços, a irmã de Ana Bernardina, Francisca Bernardina Teixeira Leite, por sua vez, casou-se com Francisco Belisário Soares de Sousa, filho de Bernardo Belisário Soares de Sousa, tio de Paulino Soares de Sousa.

Juntamente com Eusébio de Queirós (1812-1868), Rodrigues Torres e Soares de Sousa constituíram a famosa Trindade Saquarema. Eusébio era filho de Eusébio Coutinho de Queirós Coutinho da Silva, ouvidor-geral em Angola, onde Eusébio nasceu. Veio cedo com o pai para o Brasil juntar-se à Corte, onde este último exerceu diversos cargos. Eusébio casou-se com Maria Custódia Ribeiro de Oliveira, filha do comendador Manuel José Ribeiro de Oliveira, rico capitalista da praça do Rio de Janeiro e Engrácia Maria da Costa Ribeiro. Viúva, Engrácia havia se casado em segundas núpcias com José Clemente Pereira e, com este, adquirira fazendas de café em Vassouras. Filha única de Engrácia, que não teve filhos com Clemente Pereira, Maria Custódia herdou os bens do casal. Assim, também Eusébio de Queirós encontrava-se em meio à rede de proprietários que se estendia da Baixada para a nova região de expansão da agricultura escravista com o café de Serra-Acima.

Estas histórias de vida das principais lideranças conservadoras na província do Rio de Janeiro mostram os laços entre a grande propriedade e o poder na província e na cidade do Rio de Janeiro. Dessa posição, alicerçaram a extensão de seu poder em direção ao poder central, tornando-se personagens-chave da política regencial. Juntamente com Bernardo Pereira de Vasconcelos, José Clemente Pereira, Honório Hermeto Carneiro Leão, os membros da Trindade Saquarema seriam os principais articuladores do Regresso conservador e da reabertura na prática do tráfico de escravos, proibido por lei a partir de 1831. Um poder central forte foi visto como condição da realização de seus objetivos políticos. Objetivos estes que podem ser vistos através das principais questões que nortearam sua atuação, assim como a de outros conservadores da Bacia do Paraiba. Essas questões foram: a defesa dos interesses dos grandes proprietários rurais, particularmente da região da província fluminense e da Bacia do Paraíba; a defesa da escravidão, seja em sua forma dependente do tráfico internacional, seja, depois de 1850, em sua forma nacional, com a tendência à reprodução natural positiva da população escrava; o Estado monárquico centralizado e representativo na forma que este adquiriu a partir dos anos de 1840.

Perseguindo e alcançando estes objetivos, os saquaremas estabeleceram seu predomínio no interior da corrente conservadora, na província do 
Para as colocações programáticas da questão da escravidão entre as bandeiras liberais, ver CARVALHO, José Murilo de. Radicalismo e republicanismo. IN: CARVALHO, José Murilo de e NEVES, Lúcia Maria Bastos Pereira das (org). Repensando o Brasil dos Oitocentos. Cidadania, política e liberdade. Rio de Janeiro: Civilização Brasileira, 2009. Sobre a discussão no Conselho de Estado e o encaminhamento da proposta de liberdade do ventre da mulher escrava na Assembleia, ver CARVALHO, José Murilo de. A construção da ordem e Teatro de sombras, Op. Cit, 1996, e SALLES, Ricardo. E o Vale era o escravo, Op. Cit., 2008.
Rio de Janeiro e, finalmente, no próprio Império. Tal predomínio foi exercido através da direção moral e intelectual hegemônica que esses homens imprimiram em seu tempo. Foi alcançado não apenas quando eles ou políticos com eles identificados estiveram diretamente no governo, isto é, entre 1848 e 1852, nos ministérios de Olinda, Monte Alegre e do próprio Joaquim José Rodrigues Torres. Ou entre 1856 e 1857, no ministério do marquês de Caxias; entre 1868 e 1870, novamente em ministério de Rodrigues Torres, então visconde de Itaboraí; e, finalmente, entre 1875 e 1878, no ministério do já então duque de Caxias. Ou seja, durante onze anos arredondados dos 42 de que estamos falando.

Até a crise política de 1868, a concepção saquarema de Império predominou mesmo quando eles não estiveram no governo. A escravidão, que sempre defenderam, continuou sendo a força motriz das fazendas de café e da economia do Brasil. Praticamente, a única oposição de monta que sofria vinha de fora, da Inglaterra e de uma opinião pública europeia difusa. Mesmo essa oposição estava enquadrada e não trazia maiores consequências para a ordem social e política. 0 sistema político, apesar de uma ou outra crítica, como a expressada por Zacarias de Góes em 1862, em Da natureza e limite do Poder Moderador, funcionava sem abalos. Os gabinetes sucediam-se, convocados pelo imperador. A oposição se fazia no parlamento, à espera de uma oportunidade para precipitar a queda do governo e a convocação de uma de suas lideranças para compor um novo gabinete. Mesmo depois da crise de 1868, enfrentando oposições crescentes e abertas, o sistema continuou funcionando de acordo com as regras estabelecidas. As reformas propugnadas pelos liberais, seja entre as bandeiras do Partido Progressista, de 1862, seja nas páginas do A Opinião Liberal, jornal fundado em 1866, não saíram do papel. Entre maio de 1862, posse do primeiro governo chefiado por Zacarias de Góes, e julho de 1868, ano em que ele renunciou ao cargo de Presidente do Conselho de Ministros, no terceiro gabinete sob seu comando, por pressão das manobras dos conservadores e com o beneplácito do imperador, a sucessão de gabinetes liberais que estiveram no poder não quiseram, não tentaram ou não puderam implementar qualquer das reformas que propunham. É certo que a partir dessa crise, surgiu, ou ressurgiu, a proposta de substituição do regime pela forma republicana. Mas, apesar do partido republicano ter sempre engrossado suas fileiras, a partir de 1870, a monarquia foi derrubada por um golpe militar e não pelo crescimento de uma força política contestatória que já tivesse se estabelecido como uma nova direção intelectual e moral. A queda do regime monárquico, entretanto, se deu exatamente no momento em que a ordem social escravista, submetida à profunda contestação e convulsões sociais, havia sido derrubada. 0 que foi mais do que mera coincidência.

A substituição do trabalho escravo pelo trabalho livre, aliás, talvez pudesse ter sido a grande bandeira liberal. Não foi. É verdade que a proposta foi levantada por A Opinião Liberal e foi levada à discussão no Conselho de Estado durante o governo liberal, em 1867, na conjuntura marcada pela derrota dos Estados Confederados e escravistas na guerra civil norte-americana e pela mobilização nacional para a guerra contra o Paraguai. No entanto, seu encaminhamento prático, com a lei de 28 de setembro de 1871, foi realizado por um governo conservador. ${ }^{13}$

E aqui se encontra o ponto central da direção moral e intelectual que os conservadores fluminenses - os saquaremas - imprimiram na vida po- 
PARRON, Tâmis. A politica da escravidão no Império do Brasil (1826-1865). Rio de Janeiro: Civilização Brasileira, 2011. lítica do Império, o segredo de fundo do Tempo Saquarema, como definido por Ilmar R. de Mattos: a estabilidade da escravidão. Vejamos.

A data de 1850, aproximada do primeiro marco deste ensaio, é a da extinção efetiva do tráfico internacional de escravos, promovida, não por acaso, pelo gabinete saquarema de Rodrigues Torres. Diante da ameaça e dos ataques britânicos, foi impossivel manter o tráfico. Apesar de algumas tentativas de continuá-lo, em meados da década de 1850, ele estava efetivamente suprimido. E por força de um governo dos mesmos saquaremas que haviam pressionado por sua reabertura na prática, por volta de $1835 .^{14}$ 0 que explica essa conversão dos saquaremas? Em primeiro lugar, o fato de que não foi uma conversão, mas uma imposição forçada pelos ingleses. Não tivessem os navios de guerra britânicos intensificado suas apreensões, inclusive em águas territoriais brasileiras, é de se supor que o tráfico permaneceria escancarado. A pressão inglesa, no entanto, tornara a situação insustentável. Mesmo assim, houve resistências, mas o governo conservador deixou claro que, dessa vez, a lei seria para valer.

Novas condições sociais e econômicas, contudo, facilitaram a ação do governo conservador, permitindo que sua determinação fosse acatada nas regiões e localidades mais interessadas na escravidão e dominadas por sua base social, os grandes fazendeiros escravistas da Bacia do Paraiba. E isso porque a medida adotada em 1850 esteve longe de comprometer o mundo escravista da lavoura do café fluminense, nesse momento em seu auge e ainda em expansão. Derrubadas as grandes matas, montada a unidade produtiva cafeeira, os cafezais introduzidos no período ainda forneciam colheitas substanciais. Formados os grandes plantéis de cativos, as comunidades de senzala ganhavam maior estabilidade. Esse é o momento em que se melhoraram os meios de transportes e se implementaram inovações técnicas no processo de beneficiamento do café. As grandes casas de vivenda começaram a ser construídas ou passaram a sê-lo com maior frequência, os núcleos urbanos se sofisticaram. Começaram a ser distribuídos, à profusão, os títulos de nobreza entre os senhores do Vale, que ostentavam sua riqueza, poder e casavam seus filhos com aqueles dos altos dirigentes e dos membros da boa sociedade da corte.

Esse mundo, dos grandes senhores, não era um mundo isolado socialmente, como pode parecer à primeira vista. A escravidão do café, que já nascera concentrada, era, no entanto, difundida por todos os setores sociais livres, mesmo entre os mais pobres, em grande parte, originados do próprio cativeiro. Isso acontecia, se não diretamente, através da própria posse de cativos, ao menos indiretamente, através de sua participação em atividades auxiliares da lavoura cafeeira e da dependência dos grandes senhores. Essa característica dava bases a que se promovesse uma certa solidariedade entre todos os setores livres em torno da defesa, ou ao menos da tolerância, da escravidão como um modo de vida. 0 poder econômico e social dos grandes nunca esteve tão forte e o éthos senhorial-escravista, tão difundido.

\section{I}

Como já ficou evidenciado, a análise que está sendo feita parte de determinados conceitos gramscianos, particularmente de sua concepção de intelectual. Estou consciente do perigo representado por qualquer tentativa de "aplicação" de conceitos abstratos, no caso o conceito de intelectual, a 
15

Veja-se a seguinte passagem de Gramsci, em uma seção de seus Cadernos que tem exatamente o título de "Teologia - imanência - especulação", sobre a crítica realizada por Croce ao marxismo de que este seria mais uma filosofia especulativa da História, uma vez que nele a economia representaria o papel de um deus oculto a explicar situando-se fora deles, os acontecimentos, "Se o conceito de estrutura é concebido 'especulativamente', torna-se certamente um 'deus oculto'; mas ele não deve ser concebido especulativamente e sim historicamente, como o conjunto das relações sociais nas quais os homens reais se movem e atuam, como um conjunto de condições objetivas que podem e devem ser estudadas com o método da 'filologia' e não da 'especulação'. Como um 'certo' que também será 'verdadeiro', mas que deve ser estudado antes de tudo em sua 'certeza', para depois ser estudado em sua 'verdade'" (GRAMSCl, Antonio. Cadernos do cárcere. Vol. 1. Rio de Janeiro: Civilização Brasileira, 1999. p.296-297).

BURGI0, Alberto. Gramsci storico. Una lettura dei "Quaderni del carcere". Roma/Bari: Laterza, 2002.

17

GRAMSCl, Antonio. Cadernos do cárcere. Op. Cit., Vol. 2, p.15. casos concretos. Ainda mais no que diz respeito ao Império do Brasil, mais especificamente em relação ao período do Segundo Reinado. Enquanto o Brasil imperial seria uma sociedade periférica e escravista do século XIX, o conceito gramsciano diria mais respeito ao século XX e às sociedades capitalistas.

$\mathrm{Na}$ verdade, menos que uma aplicação, trata-se de realizar um desenvolvimento de natureza teórico-historiográfica, tendo como um dos pontos de partida - o outro se constitui no próprio exame dos fatos -, para o caso do Império, daquilo que Gramsci chamava de "critérios ou cânones práticos de interpretação". Esta fórmula expressa o reconhecimento em Gramsci dos princípios teórico-metodológicos básicos do procedimento historiográfico: a singularidade e a facticidade do processo histórico, acessível ao conhecimento pela comprovação empírica realizada através dos métodos da filologia. Esses métodos, entretanto, não bastam em si para produzir o conhecimento histórico. Sua colocação em prática é sempre uma operação de validação empirica dos cânones de interpretação histórica, e, portanto, em sua transformação em interpretações históricas específicas, concretas e singulares. Essas interpretações, por sua vez, rebatem sobre estes mesmos cânones, transformando-os, enriquecendo-os e mesmo os negando. ${ }^{15}$ Os cânones de interpretação são, assim, condição necessária e atuante para o trabalho filológico, que, caso contrário, restaria desprovido de sentido e impossibilitado diante da massa documental fragmentada legada pelo passado. A própria noção de que o passado lega essa massa implica em uma subjetividade teórica. Subjetividade da qual decorrem os cânones de interpretação.

Como salientou Alberto Burgio, em Gramsci storico, o pensamento de Gramsci é antes de tudo um pensamento histórico (eu acrescentaria especificamente historicista) sobre a História e, mais particularmente, sobre a Modernidade ocidental. ${ }^{16}$ Suas categorias estão longe de serem abstratas. $E_{1}$ na medida em que estamos tratando da formação do Estado nacional brasileiro, a partir da expansão do que justamente está sendo designado como uma segunda escravidão, ou de forma ainda mais pertinente ao tema proposto, escravidão nacional, o alinhamento prévio das categorias é menos abstrato do que parece à primeira vista. As categorias remetem diretamente a processos históricos abrangentes que estavam em curso como a modernidade capitalista ocidental - e sem cuja compreensão a interpretação do Império seria impossível.

Na abertura do Caderno do Cárcere de número 12, que trata da questão dos intelectuais, tema recorrente em suas reflexões e de interesse direto para esse ensaio, Gramsci indagava: "Os intelectuais são um grupo autônomo e independente, ou cada grupo social tem sua própria categoria especializada de intelectuais?" Formulada de uma maneira teórica, a questão dizia respeito um problema histórico concreto, intimamente ligado ao tema aqui tratado: a formação e ao papel dos intelectuais no mundo moderno, e, mais especificamente nos séculos XIX e XX. ${ }^{17}$

Em sua análise desse processo histórico, Gramsci identificou duas formas mais importantes de formação de intelectuais, até aquele momento, no cenário ocidental. Por um lado, todo grupo social, "nascendo no terreno originário de uma função essencial no mundo da produção econômica, cria para si, ao mesmo tempo, organicamente uma ou mais camadas de intelectuais". Essas camadas de intelectuais é que dariam ao grupo "homogeneidade e consciência da própria função, não apenas no campo econômico, mas também social e político"18. Por outro lado, todo 
GRAMSCI, Antonio. Cadernos do cárcere. Op. Cit. Vol.3, p.36-48; SALLES, Ricardo. E o Vale era os escravo, 0p. Cit., p.26.

22

MORERA, Esteve. Gramsci's Historicism. A Realist Interpretation. Londres/Nova York: Routledge, 1990. grupo "essencial", na medida em que emergia na história a partir de uma estrutura econômica anterior e como expressão do desenvolvimento desta estrutura, teria encontrado "categorias intelectuais preexistentes, as quais apareciam, aliás, como representantes de uma continuidade histórica que não foi interrompida nem mesmo pelas mais complicadas e radicais modificações das formas sociais e políticas. ${ }^{19}$ Dessa forma, historicamente, se formavam "categorias especializadas para o exercício da função intelectual (...), em conexão com todos os grupos sociais, mas sobretudo em conexão com os grupos sociais mais importantes", especialmente em relações mais amplas e complexas com o grupo social dominante - lembremos que, enquanto tal, só podem ser pensados como Estado. Uma das características mais marcantes de todo grupo que se desenvolve no sentido do domínio é sua luta pela assimilação e pela conquista "ideológica" dos intelectuais tradicionais. ${ }^{20}$

A atuação dos intelectuais, forjando em determinado grupo social sua "homogeneidade e consciência da própria função, não apenas no campo econômico, mas também social e político", não é somente um processo referido às relações internas a esse grupo, mas ao conjunto da formação social, de suas classes e camadas sociais em uma determinada relação social de forças. Tal relação social de forças, ainda segundo Gramsci, acontece em três momentos distintos e simultâneos. Um momento ligado à "estrutura objetiva, independente da vontade dos homens", onde se configuram os grandes agrupamentos sociais em termos de número, distribuição geográfica e espacial, concentração ou dispersão em grandes ou pequenas unidades de produção, etc. 0 segundo é aquele em que se dá a "relação de forças políticas, ou seja, a avaliação do grau de homogeneidade, de autoconsciência e de organização alcançado pelos vários grupos sociais", abarcando desde a consciência coletiva de seus interesses econômico-corporativos até sua formulação enquanto identidade e interesses universais, que incorporam e modificam os interesses dos demais grupos sociais tornados subalternos. Este é o momento em que se coloca a questão do Estado e da direção moral e intelectual da sociedade. Finalmente, há o momento decisivo da relação político-militar em que o que está em jogo é a própria ruptura ou continuidade da ordem e, eventualmente, do bloco histórico. Na história real, esses momentos se entrelaçam, tanto no plano social e econômico quanto no plano territorial. ${ }^{21}$

A caracterização dessas dimensões das relações sociais como "momentos" pode parecer, inicialmente equivocada, no sentido de dar a impressão de sua sucessividade e não simultaneidade. No entanto, 0 próprio Gramsci explicitou que são momentos simultâneos. Há, contudo, um outro aspecto que justifica a manutenção da expressão "momentos" para dar conta da complexidade dessas relações sociais. Trata-se do fato de que, como observou Esteve Morera, aproximando a análise gramsciana da concepção braudeliana de múltiplas temporalidades do processo histórico, cada um desses momentos tem sua própria temporalidade. ${ }^{22}$ Essas temporalidades, por sua vez, implicam níveis distintos, ainda que interdependentes de agência, ou protagonismo.

Todos esses momentos, inclusive o primeiro, aquele da "estrutura objetiva, independente da vontade dos homens", e não apenas o segundo, da política e da hegemonia, e o terceiro, do enfrentamento e eventualmente da ruptura, não podem ser entendidos sem levar em consideração as práticas sociais protagonizadas por indivíduos e grupos de indivíduos concretos, identificados no tempo e no espaço. A estrutura é objetiva no 
TROUILLOT, Michel-Rolph. Silencing the Past. Power and the Production of History. Boston: Beacon Press, 1995. p.23-24. sentido de que é uma situação histórica, coletiva, isto é, social, dada, e não no sentido de que ela não seja objeto de suas ações e práticas. Na prática, tal situação histórica só existe protagonizada por grupos e indivíduos, que atuam nela e sobre ela de forma reflexiva. Por isso, Gramsci entende que todos os homens são intelectuais, no sentido de que todos atuam, em diferentes práticas, niveis e de diferentes formas, na situação histórica. Desde o plano das transformações moleculares, aparentemente dispersas, que se processam no cotidiano, até as grandes ações que visam um efeito sobre 0 conjunto. Pode-se estabelecer, então, uma distinção, que é muito mais teórica e inicial, do que exatamente histórica, entre duas faces de um mesmo fenômeno histórico: hegemonia de classe e hegemonia política e intelectual. A primeira embasa a segunda e esta constrói a primeira. A distinção é importante no sentido de evitar a antromoformização ou a subjetivação extremada da classe social. 0 que, por si só, acaba deixando os processos históricos especificos sem explicação, ou apenas estabelece explicações iniciais e superficiais.

A principal distinção desses processos correlatos diz respeito aos niveis de protagonismos históricos envolvidos. Para explicitar o ponto, vou me valer de uma colocação de Michel-Rolph Trouillot, em Silencing the Past. Esse autor considera que a História, enquanto processo social, envolve a participação das pessoas através de três tipos de capacidades: 1) como agentes, ou ocupantes de posições estruturais; 2) como atores, em constante interface com o contexto e; 3 ) como sujeitos, quer dizer como vozes conscientes de suas "vocalidades".

No primeiro caso, essas capacidades dizem respeito ao pertencimento social das pessoas a determinadas camadas e conjuntos, tais como classes e status, e aos papéis correlatos a esses pertencimentos. "Trabalhadores, escravos, mães são agentes". As capacidades dos atores estão ligadas a situações históricas particulares, que situam no tempo e no espaço sua existência e sua compreensão. Assim, por exemplo, as especificidades que distinguem a escravidão afro-americana nos Estados Unidos e no Brasil vão além de meras variações estatísticas, e dizem respeito a particularidades históricas das diferentes situações. Finalmente, como sujeitos, as pessoas demonstram sua capacidade de agir a partir de determinados propósitos e de verbalizar esses propósitos e ações. 0 exemplo de Trouillot, neste último caso, é que os trabalhadores não entram em greve como agentes, mas como sujeitos de uma ação que foi e é verbalizada. ${ }^{23}$

Essas três capacidades de Trouillot, sem as quais é impossivel, compreender o papel das pessoas na História, são em tudo semelhantes aos três momentos simultâneos e interconectados, distinguidos por Gramsci no que diz respeito à análise das relações de forças sociais presentes em uma situação histórica dada. Buscando combinar as distinções de Trouillot com os momentos de Gramsci, pode se dizer que a hegemonia de classe ou social corresponderia a processos gerais, abrangentes, processos que envolvem o maior número (Gramsci), em que os homens aparecem em sua condição e capacidade de agentes e atores. Na hegemonia política os homens, não necessariamente os mesmos homens, em menor número e individuados como grupos de pessoas ou individualmente, aparecem mais em sua capacidade de sujeitos. Esse refinamento visa evitar imprecisões e atalhos historiográficos no caso das análises de momentos e situações históricas específicos. Essas imprecisões e atalhos, algumas vezes, são apenas narrativos, sem maiores implicações. Outras, quando elidem problemas ou 
dificuldades reais da interpretação em curso, têm implicações teórico-interpretativas mais graves.

É a partir dessas considerações genéricas que Gramsci fez sobre os intelectuais, que abordarei a questão de quem era, como se formou e 0 que e quem representava o grupo dirigente do Império. Uma elite política homogênea, portadora de um projeto próprio para a nação e para o Estado que se formavam? Uma elite social que, apoderando-se do governo, nele se reproduzia e o utilizava para seus próprios interesses? Elites regionais que se revezavam, se digladiavam e se acomodavam no controle do governo central? Ou esse grupo dirigente seria um grupo de políticos e dirigentes intelectuais - vinculados a uma classe específica, a classe senhorial, que exercia sua dominação sobre o conjunto da sociedade nacional?

Sobre o pensamento de Gramsci como uma reflexão teórica de natureza fundamentalmente histórica, ver o livro de Alberto Burgio, Gramsci storico, Op. Cit. Que sua preocupação com o século XIX italiano era grande, pode ser constatado pela carta que ele escreveu à cunhada em 25 de março de 1929, quando ainda estava se preparando para se lançar ao trabalho de redação de seus Cadernos, em que ele elencava três grandes temas de estudo: 1) uma história da Itália no século XIX, com especial atenção para a questão da formação e desenvolvimento dos intelectuais; 2) teoria da história e da historiografia; 3) americanismo e fordismo (BUTTIGIEG, Joseph. Introduction. In: GRAMSCI Antonio. Prison Notebooks. 3 Vols. Columbia: Columbia University Press, sd.

25

0 "tardio" vai entre aspas uma vez que a expressão traz em si uma visão linear do processo de evolução histórica. Entretanto, por sua consagração no senso comum historiográfico e por não ser este o tema direto deste texto, a utilizo, entre aspas, por comodidade. Esse tipo de abordagem, de vertente marxista, das experiências alemã e italiana, supõe que essas sejam pensadas a partir de um modelo de revolução burguesa. Essa compreensão tem sido colocada em xeque pela recente historiografia. Esta questiona a própria noção de revolução burguesa, fórmula simplificadora para dar conta do processo geral de desenvolvimento do capitalismo industrial somado ao, e mesmo impulsionado pelo, estabelecimento de Estados nacionais. A caracterização como tardia ou pelo alto desses processos de revolução-restauração, ou de revolução passiva, na concepção gramsciana, em que a transformação social é assegurada por acomodações entre os grupos sociais ascendentes e antigos grupos dominantes, denotaria os compromissos econômicos ou mesmo a subordinação política que a burguesia desses países teria aceitado em relação a classes e grupos dominantes agrários do Antigo Regime para viabilizar seu desenvolvimento econômico. Tal caracterização teria como parâmetro de comparação os "modelos" clássicos inglês e francês. A crítica desse esquema, no entanto, já foi produzida a partir de uma perspectiva marxista. Ver MAYER, Arno. A força da tradição. A persistência do Antigo Regime (1848 - 1914). São Paulo: Companhia das Letras, 1987.
A similitude entre a indagação de Gramsci e aquela que aqui se faz não se dá apenas no plano da teoria. Ela também se dá no campo da própria historiografia, uma vez que tanto os problemas aqui tratados quanto aqueles que mereceram a atenção do revolucionário italiano sucederam em uma mesma época histórica. Uma mesma época histórica não apenas no que diz respeito ao tempo cronológico dos três primeiros quartos do século XIX, mas também do ponto de vista de uma mesma problemática histórica, na medida em que suas indagações partiam de questões que remontavam à formação da modernidade ocidental, em geral, e, mais especificamente, ao século XIX europeu. Gramsci preocupava-se, em particular, com os desdobramentos da Revolução Francesa e do período da Restauração, com a formação dos Estados nacionais, a ascensão da burguesia e o estabelecimento do capitalismo industrial como modo de produção dominante. ${ }^{24} \dot{E}$ certo que o Brasil do século XIX não experimentou diretamente qualquer desses processos. Indiretamente ou em seus aspectos "externos", a história do Brasil no período, entretanto, tem a ver com tudo isso e com a ascensão da burguesia e do desenvolvimento do capitalismo industrial.

Os elementos da análise gramsciana, ou de seus critérios ou cânones de interpretação, como ele queria, que lançam luz sobre a história brasileira no século XIX dizem respeito igualmente a aspectos mais diretos e internos. Isso porque a reflexão gramsciana se deu a partir de uma experiência "tardia" e relativamente periférica - a italiana - de desenvolvimento do capitalismo industrial e, principalmente, do estabelecimento de um Estado territorial nacional. ${ }^{25}$ Apesar de a construção do estado nacional no Brasil não ter sido tardia e de não ter criado as condições para o desenvolvimento do capitalismo e de uma burguesia, os mesmos cânones de interpretação histórica podem ser utilizados dadas correlações que podem ser identificadas nas duas experiências.

Em primeiro lugar, tais correlações devem ser buscadas no papel desempenhado por grupos sociais "antigos" ligados às funções de governo, intelectuais tradicionais no vocabulário gramsciano, na formação dos Estados nacionais italiano e brasileiro. Nos dois casos, grupos dirigentes oriundos do Antigo Regime - aquele aglutinado em torno da monarquia do Piemonte-Sardenha, na Itália, e a elite política luso-brasileira, no Brasil conduziram os processos de construção dos Estados nacionais. Tendo que lidar com pressões externas do mundo pós-Revolução Francesa e pós-Napoleão, e com forças internas, em larga medida, galvanizadas e potencia- 
lizadas por esses acontecimentos, esse grupos, em situações periféricas e subalternas, ainda que muito distintas, no contexto internacional, tiveram que se atualizar, ou, na linguagem gramsciana, passar por um processo de aggiornamento, para garantir sua sobrevivência. Nesse sentido, aceitaram e empreenderam o estabelecimento de Estados liberais, ainda que com alto grau de restrição à participação institucional e à representação política. Do ponto de vista social, estes grupos, ainda de formas diferentes, integraram-se ou se aliarem, em maior ou menor grau, a classes economicamente ascendentes. Na Itália, a aristocracia piemontesa aliou-se à burguesia e aos setores médios do norte, e também à burguesia e a setores da aristocracia agrárias que se modernizavam, do centro e do sul da península. No Brasil, a elite política luso-brasileira, que desempenhou papel central no processo de independência e afirmação do Estado imperial, aliou-se aos plantadores escravistas da região Sudeste. Em alguns casos, seus membros tornaram-se eles mesmos plantadores. Por outro lado, tanto no reino da Itália quanto no Império do Brasil, grupos social e economicamente dominantes tradicionais em outras regiões - os latifundiários do Mezzogiorno italiano e os senhores de terras e de escravos de outras partes da antiga América portuguesa mantiveram seu poder, mesmo que em posição de subalternidade.

São essas especificidades históricas, além da própria contemporaneidade das experiências de construção de Estados liberais no contexto de afirmação do capitalismo histórico, que permitem ainda mais a assimilação dos conceitos gramscianos para o caso do Brasil. Com efeito, o mundo europeu do século XIX não era integralmente um mundo burguês, ao menos no sentido de que já tivesse deixado para trás as antigas classes dominantes. Depois de 1793 e de Napoleão, todos haviam aprendido suas lições. A burguesia, na verdade, nunca teria levado as coisas - como de fato não levou, já que foram os jacobinos que o fizeram - ao extremo do Terror, não fosse a intransigência da velha ordem. Passada e debelada a tormenta da Revolução e derrotado o furacão napoleônico, os velhos grupos dominantes no Antigo Regime mantiveram posições de mando e prestígio social depois da Restauração. Fizeram-no, no entanto, os mais bem-sucedidos deles, não como uma volta ao passado ou como expressão de uma resistência obstinada da velha ordem, em lenta retirada diante da pressão burguesa. Fizeram-no através de um processo de aggiornamento, de revolução passiva e revolução-restauração - fórmulas gramscianas para dar conta desse processo histórico - em que se transformavam para se adaptar à ascensão da burguesia e do capitalismo industrial, ao mesmo tempo em que, ao fazê-lo, moldavam essa ascensão. Em lugar algum da Europa, com exceção da França, a burguesia, ou seus representantes políticos, dirigiu 0 processo de transformações econômicas, sociais e políticas que atravessou, em graus diferentes, os diversos Estados territoriais e nacionais europeus. Ela, no entanto, foi a força social que catalisou essas mudanças. Nem os trabalhadores, ainda que tenham terminado por impor, ali pela virada do século $X X$, a marca democrática ao liberalismo burguês, nem os reacionários prevaleceram. A aristocracia que então, em quase toda a Europa, agora com a exceção inversa da Rússia czarista, ainda dominava a política, era uma aristocracia transformada, em parte aburguesada, aggiornata. Foi a compreensão desse fenômeno como acontecimento particular italiano, mas também como acontecimento geral do século XIX europeu, que fez com que Gramsci considerasse a revolução passiva como um tema de "interpretação da Era do Risorgimento e de qualquer época complexa de transfor- 
GRAMSCI, Antonio. Cadernos do cárcere. Vol.5. Rio de Janeiro: Civilização Brasileira, 2002. p. 331-332.

27

TOMICH, Dale. Through the Prism of Slavery: Labor, Capital, and World Economy. Boulder: Rowman \& Littlefield, 2004

28

Ibidem.

29

Sobre o desenvolvimento da escravidão no Brasil, a partir da expansão do café, em suas conexões com outras áreas escravistas do Caribe e o desenvolvimento de um mercado capitalista internacional, alavancado pela Revolução Industrial, ver MARQUESE, Rafael de Bivar e TOMICH, Dale. 0 Vale do Paraiba escravista e a formação do mercado mundial do café no século XIX. In: GRINBERG, Keila e SALLES, Ricardo (org.) O Brasil imperial. Vol.2. Rio de Janeiro: Civilização Brasileira, 2009

30

SALLES, Ricardo. E o Vale era o escravo, 0p. Cit., p.41-75, esp. p.43-46. mações históricas (...) como critério de interpretação, na ausência de outros elementos ativos de modo dominante". ${ }^{26}$ A revolução passiva deveria ser entendida como chave de interpretação de toda uma época histórica que se abrira depois da Revolução Francesa.

Em segundo lugar, as correlações entre as histórias do Brasil e da Itália no século XIX dizem respeito às suas respectivas inserções periféricas, ainda que diferenciadas, no sistema internacional do capitalismo histórico. Mesmo os aspectos mais diretamente capitalistas da modernidade do século XIX, como a ascensão da burguesia e o desenvolvimento do capitalismo industrial, em suas repercussões de ordem internacional, também faziam parte, ainda que de maneira indireta, do mundo do Império do Brasil. $\mathrm{Na}$ Itália, o conjunto de circunstâncias históricas - repercussões da Revolução Francesa, invasões e guerras napoleônicas, entrada em pauta da questão nacional, tanto do ponto de vista do espaço dos Estados territoriais no contexto internacional, como protagonizado por governos e dos grupos dirigentes, quanto do ponto de vista da demanda por novos espaços políticos e sociais, como pretendido pelas classes médias e populares - levou a processos de compromisso que acabaram por demandar e criar condições para o desenvolvimento do capitalismo industrial no norte da península. No Brasil, o mesmo conjunto de circunstâncias históricas, agregadas a outras condições específicas, tais como o processo de independência e a expansão de uma nova escravidão diretamente dependente e impulsionadora do mercado mundial, resultaram na formação da classe senhorial enquanto classe histórica nacional, isto é, articulada em torno da construção de um Estado nacional.

Não se pode entender a escravidão brasileira do século XIX fora dos quadros do que Dale Tomich denominou de segunda escravidão. ${ }^{27}$ Uma escravidão afro-americana renovada e praticada em intensidade e escala nunca antes vistas no Sul dos Estados Unidos, no Brasil e em Cuba, umbilicalmente articulada com os circuitos internacionais de capitais e mercadorias, com o processo de formação de mercado de consumo e insumos, inclusive de mão-de-obra, em escala atlântica, propiciados pelo desenvolvimento do capitalismo industrial. Não se trata de entender os acontecimentos e processos de formação do sistema-mundo e do capitalismo histórico somente sob o prisma dominante industrial europeu e do norte dos Estados Unidos. É preciso vê-los também sob o prisma dessa segunda escravidão. ${ }^{28} \mathrm{~A}$ articulação intrínseca desses processos representou, no Brasil, o desenvolvimento de uma nova escravidão enquanto sistema econômico histórico e a ascensão de uma nova classe dominante, a classe senhorial e não a burguesia e o capitalismo industrial, ainda que esses pares fizessem parte, com papéis distintos, complementares e, ao mesmo tempo, contraditórios, do mesmo sistema internacional de desenvolvimento capitalismo histórico. ${ }^{29}$ Uma escravidão que foi também uma escravidão nacional..$^{30}$ Que, além de se desenvolver com o mercado mundial capitalista, o fez no contexto de afirmação dos Estados nacionais, como loci de agência por excelência na arena internacional, tornada mais decisiva para a sobrevivência, expansão e sucesso externo e interno de grupos e classes sociais, como a própria classe senhorial brasileira.

Todos os eventos e processos sumariamente enumerados acima estiveram ligados à construção do Império do Brasil. Desde a vinda da corte portuguesa para a América, passando pelo Congresso de Viena, pelos desdobramentos da Revolução do Porto, pela proclamação da independência com a 
manutenção da fórmula monárquica, pelo Primeiro Reinado e a abdicação de dom Pedro I, em 1831, até a reafirmação e consolidação da monarquia, com o triunfo do Regresso, a partir de 1838, em moldes político-ideológicos semelhantes aos da monarquia de julho na França. Em certo sentido, também o Império do Brasil nasceu a partir de um processo de aggiornamento de elementos oriundos da antiga monarquia portuguesa, a partir de sua inserção no contexto americano, que, exatamente naquele momento, vivia o processo recrudescimento da escravidão, resultante e resultando da íntima conexão entre a economia brasileira e o mercado capitalista internacional. Só isso, contudo, não basta para dar conta da complexidade dos processos políticos, sociais e econômicos que estavam em curso e que terminaram por embasar a consolidação do Império com o advento do Segundo Reinado. A formação da classe senhorial e de uma nova camada de intelectuais autorizam a caracterização do Império do Brasil como um caso de revolução passiva, muito mais que o mero processo de aggionarmento de antigas camadas dirigentes e dominantes. 0 Império do Brasil foi um império monárquico, agrário e escravista, de feição burguesa, tanto no sentido econômico, quanto no sentido moral e intelectual. Esse Império repousou sobre uma hegemonia de classe - a da classe senhorial escravista nucleada em torno da produção cafeeira da Bacia do rio Paraíba do Sul - construída a partir da direção moral e intelectual exercida pelo grupo saquarema fluminense e mantida pela hegemonia política conservadora que resultou desse processo.

Os processos de construção do Estado nacional brasileiro e o italiano, além das experiências russa e prussiano-alemã, no século XIX, tiveram mais elementos comuns entre si do que o fato de serem coetâneos. Ambos ocorreram, em primeiro lugar, nos quadros do desenvolvimento do mercado internacional impulsionado pelo capitalismo histórico no século XIX. 0 primeiro aconteceu sobre as bases materiais de uma segunda escravidão em expansão, ainda que em espaço geograficamente delimitado, consolidando o domínio da classe senhorial, enquanto classe nacional. 0 segundo, sob a égide da consolidação do poder da burguesia do norte da península. Do ponto de vista político, os dois processos históricos se desenvolveram como experiências de revolução passiva, ou de revolução-restauração. Isto é, caracterizaram-se por acomodações e compromissos entre forças sociais e formas institucionais vinculadas a regimes sociais pré-existentes e novas forças sociais e formas institucionais nascentes. Na Itália, o Estado nacional unificado surgiu de um processo de adequação entre a aristocracia dirigente piemontesa, a burguesia do Norte e setores agrários do Sul. Adequação essa estabelecida às expensas das massas camponesas do Sul e da subordinação política e ideológica dos grupos políticos radicais e democráticos à direção intelectual dos moderados nucleados em torno da monarquia piemontesa. Já no Brasil, a consolidação da forma institucional monárquica e imperial, construída sob a direção intelectual e moral do partido conservador, não se deu a partir de clivagens sociais e regionais marcantes entre os grupos sociais dominantes e médios. A manutenção e a expansão da segunda escravidão, em ritmo e dimensões dados por sua intima conexão com o mercado internacional capitalista, marcaram a organicidade social e econômica da hegemonia senhorial e da ordem imperial.

É essa contemporaneidade dessas diversas experiências históricas que conferem valor heurístico à fórmula gramsciana da revolução passiva. Em relação a esse ponto, John Davis coloca que a questão é menos saber 
DAVIS, John. Introduction: Gramsci and Italy's Passive Revolution In:___ (org.). Gramsci and Italy's Passive Revolution. Londres: Croom Helm, 1979. p.17.

32

Ibidem, p.24; GINSBORG, Paul. Gramsci and the Era of the Bourgeois Revolution. In: DAVIS, John (org.), Op. Cit.
33

KOLCHIN, Peter. Unfree Labor. American

Slavery and Russian Serfdom. Cambridge (Massachussets): Belknap Press, 1985. BOWMAN, Shearer Davis. Masters \& Lords. Mid $19^{\text {th }}$ Century U.S. Planters and Prussian Junkers. Oxford: Oxford University Press, 1993. LAG0, Enrico Dal. Agrarian Elites. American Slaveholders and Southern Italian Landowners - 1815-1861. Baton Rouge: Louisiana State University Press, 2005. se as interpretações de Gramsci estavam ou não corretas, e mais se elas são adequadas para identificar aspectos das relações de forças sociais e da organização política particulares à Itália. Nesse sentido, ele, comentando o texto de Paul Ginsborg na coletânea por ele organizada sobre o tema da revolução passiva na Itália, considera que as relações entre os setores das classes médias agrárias e urbanas foram cruciais para determinar 0 avanço ou 0 atraso das mudanças econômicas em toda a Europa do século XIX. ${ }^{31}$ Tanto a parceria entre os interesses manufatureiros e agrários quanto o papel desempenhado pela questão agrária, quer dizer a absorção do campo pelas relações de produção capitalistas, não foram um problema particular da Itália, mas uma caracteristica geral das revoluções burguesas europeias em geral. A base econômica e social do sistema politico na Itália poderia, assim, ser comparada com a França de Louis Philippe e a Alemanha de Bismarck. ${ }^{32}$

Podemos estender ainda mais o campo de comparação e abrangência do tema da revolução passiva no século XIX. A história do próprio mundo capitalista e liberal europeu, melhor seria dizer atlântico, não se esgota numa dialética interna entre setores das classes médias urbanas $X$ setores agrários oriundos do Antigo Regime, mas deve, necessariamente, incorporar as experiências de expansão de formações sociais da periferia do sistema na primeira metade do século XIX, baseadas no trabalho compulsório, como no caso da Rússia e dos regimes escravistas da América, ou coagido e proletarizado, como no Mezzogiorno italiano. As comparações entre os casos da Rússia, da Prússia e do Mezzogiorno italiano, por um lado, e do Sul dos Estados Unidos já foi realizada. ${ }^{33} \mathrm{~A}$ experiência do Império do Brasil, como esboçado até aqui, com sua solução monárquica e imperial e a preeminência da classe senhorial sobre o Estado nacional, presta-se ainda mais para a comparação.

As colocações de Gramsci, assim como os comentários de Davis sobre o texto de Ginsborg sobre esse assunto, suscitam duas questões para o entendimento do Brasil do século XIX. A primeira diz respeito às condições materiais, econômicas e sociais desse processo de absorção. Não se trata de presumir, internamente, um processo de revolução burguesa, industrialização ou modernização, sempre parcial, incompleto ou frustrado, que estaria presente, de forma latente, na história do Império, mas de entender como se deram as características do desenvolvimento nacional da segunda escravidão no Brasil, associado à formação e expansão da classe senhorial e do Estado nacional imperial, através de sua inserção específica nos quadros mais gerais do desenvolvimento do sistema capitalista histórico em escala mundial.

A segunda questão diz respeito à dimensão mais diretamente política desse processo. Mais especificamente, ao papel de hegemonia e direção intelectual e moral exercido pelos conservadores sobre os liberais e sobre a construção do Estado no período imperial a partir de 1835, de forma praticamente inconteste até a crise de 1868 , e mesmo depois, ainda que sofrendo constantes e crescentes contestações, que resultaram, em 1889, na queda do Império. A partir de sua derrota nas revoltas de 1842, em São Paulo e Minas Gerais, os setores que se opunham ao governo do autodenominado Partido da Ordem, em vias de se tornar o partido conservador, nessas províncias e também no Rio de Janeiro, e que viriam a constituir o partido liberal, sofreram um processo histórico de subordinação política. De uma maneira ou de outra, até 1868, a maioria dos intelectuais liberais ter- 
34

Sobre as revoluções de 1842, em perspectiva que inspirou essas colocações, ver IImar Rohloff de Mattos. 0 tempo saquarema, 0p. Cit., 1987 e LENHARO, Alcir. As tropas da moderação, o abastecimento da corte na formação política do Brasil, 1808-1842. Rio de Janeiro: Secretaria Municipal de Educação, 1978. Ver ainda HÖRNER Erik. Em defesa da Constituição. A guerra entre rebeldes e governistas (1838-1844). 2010. (Tese de Doutorado). Faculdade de Filosofia, Letras e Ciências Humanas, Universidade de São Paulo, São Paulo, 2010.

35

PARRON, Tâmis. Op. Cit.

36

Sigo aqui as informações e a interpretação feita por João Carlos Escosteguy Filho no segundo capítulo de seu trabalho sobre a direção saquarema e o debate sobre o tráfico internacional no Senado do Império (ESCOSTEGUY FILHO, João Carlos. Tráfico de escravos e direção saquarema no Senado do Império do Brasil. 2010. (Dissertação de Mestrado). Instituto de Ciências Humanas e Filosofia, Universidade Federal Fluminense, Niterói, 2010. 79 e ss.

37

Anais do Senado, Vol. IV, p.346, apud ESCOSTESGUY FILHO, Op. Cit., p.121.

38

Ibidem.

39

lbidem. minou sendo absorvida pela direção intelectual e moral conservadora, seja por sua aceitação das regras do jogo, a partir das derrotas de 1842 e 1848, e da agenda política definida pelos conservadores, seja ainda pela adesão de alguns às fileiras conservadoras. Mesmo quando os liberais chegaram a formular bandeiras específicas, sendo a mais importante delas, a da abolição gradual da escravidão, continuaram, no entanto, uma vez no governo, mostrando-se incapazes de implementá-las. Essa incapacidade de realizar seus objetivos se deu menos por qualquer tipo de incoerência doutrinária e mais por sua pouca organicidade histórica em relação à principal força econômica e social sobre a qual repousava o poder imperial, os grandes plantadores escravistas do Sudeste, notadamente do Vale do Paraiba. Os liberais, tampouco, estiveram orgânica e historicamente vinculados a qualquer outra configuração social e territorial de poder alternativa. É fato que houve plantadores da região do café que eram liberais ou apoiavam os liberais. Nunca, no entanto, deram o tom da política na região. Quando tentaram, em 1842, foram derrotados. As vitórias do governo do Partido da Ordem sobre os rebeldes do Rio de Janeiro, de São Paulo e Minas Gerais significou uma espécie de acerto de contas doméstico aos setores dominantes, inclusive e principalmente proprietários rurais, na região da Bacia do Paraíba e do Sudeste. Foi essa vitória que abriu o caminho para sua hegemonia duradoura. ${ }^{34}$

Inversamente, a vitória do governo do Partido da Ordem foi propiciada por sua maior organicidade com os interesses dos grandes plantadores escravistas produtores de café. Essa organicidade havia se construído inequivocamente na defesa da reabertura na prática do tráfico internacional de escravos, a partir de 1835-37, e na vitória da política do Regresso, estabelecida no ano seguinte..$^{35}$ Esses dois eventos estavam solidamente embasados no apoio da maioria dos grandes proprietários escravistas do Vale, que, nesse momento, experimentavam o crescimento impar de sua produção de café inserida na expansão do mercado mundial capitalista. Ao soldar a ordem política liberal e os interesses escravistas, os conservadores assumiram plenamente a natureza contraditória dessa inserção.

Isso foi explicitado com clareza cristalina, em 1843, por Bernardo Pereira de Vasconcelos, mineiro, veterano dos embates do Primeiro Reinado e da Regência, e, até aquele momento, a principal figura do grande movimento conservador, centrado na expansão escravista, que imprimia sua marca ao Império. ${ }^{36} \mathrm{Na}$ sessão de 25 de abril daquele ano, o Senado debatia um projeto de lei que estabelecia em dois anos o tempo necessário de residência no país para a naturalização de estrangeiros no Brasil. 0 senador Lopes Gama justificou seu voto a favor dizendo que não só era necessário facilitar a vinda, desejada, de estrangeiros brancos, como também era preciso coibir a vinda de africanos, o que terminava por inibir a imigração dos primeiros. E citava como prova de sua afirmação a experiência dos Estados Unidos. Lá, os imigrantes procuravam os estados em que a escravidão fora abolida. Vasconcelos, que havido rido durante a argumentação do cole$\mathrm{ga}$, tomou a palavra e contra argumentou que agir dessa maneira estimularia "tendências barbarizadoras que hão de resultar da abolição do tráfico de africanos". ${ }^{37} 0$ senador Costa Ferreira interpelou, então: "Já a África civiliza!". Vasconcelos respondeu sem titubear: "É uma verdade; a África tem civilizado a América...." ${ }^{38} \mathrm{E}$ completou citando o mesmo exemplo dos Estados Unidos, brandido por seus adversários, dizendo que os grandes homens norte-americanos provinham exatamente das regiões escravistas daquela república. ${ }^{39}$ 
QUEIROZ, Tatiane Rocha. O Regressismo e o Progressismo no periódico 0 Brasil (1840/1843). 2011. (Dissertação de Mestrado). Faculdade de Formação de Professores, Universidade do Estado do Rio de Janeiro, São Gonçalo, 2011. p.11-17 .

41

O Brazil, 23/06/1840, apud QUEIROZ, Tatiane Rocha, Op. Cit., p.31.

42

Ibidem, 28/07/1840, ibidem, p.31.

43

MATTOS, IImar R. O tempo saquarema, Op. Cit.
Os liberais, por seu lado, mostraram-se incapazes de assumir a crítica radical da natureza contraditória dessa mesma inserção. Estiveram sempre na defensiva, sendo tímidos e buscando se justificar diante do pragmatismo dos conservadores.

No plano especificamente político, os conservadores demonstraram na prática a soldagem entre o liberalismo monárquico e a escravidão no Brasil. Inicialmente, ao não reagirem pelas armas à antecipação da maioridade do imperador em 1840, imposta por seus adversários e que pôs fim a seu governo. Fizeram-no em nome da ordem constitucional, apostando que a vitória de seus inimigos não teria forças para inviabilizar ou reverter a obra do Regresso. Obra que nada mais era que a soldagem específica do liberalismo monárquico com a escravidão. Isso fica claro quando acompanhamos seus posicionamentos, na conjuntura crítica de 1840 , pelas páginas de 0 Brasil, jornal fundado em junho desse mesmo ano por Justiniano José da Rocha e Firmino Rodrigues Silva sob inspiração, encomenda e apoio diretos do governo, através do ministro da Justiça, Paulino José Soares de Sousa, e Eusébio de Queirós. ${ }^{40}$

Uma semana após a sua fundação, o jornal tecia duras críticas àqueles que pretendiam antecipar a maioridade do imperador. Considerava a alegação de que este fato reforçaria as instituições e, assim, seria decisivo para o apaziguamento do Império, naquela altura enfrentando as revoltas da Balaiada, no Maranhão, e da Farroupilha, no Rio Grande do Sul, uma perigosa panacéia. 0 momento requeria uma institucionalidade forte e a antecipação da maioridade do imperador, ao violar a constituição, teria consequências irremediáveis neste sentido. Caso a Câmara o fizesse, seria responsável por uma revolução. Diante dessa ameaça, o jornal e o governo clamavam "salvem a constituição do Império e a monarquia".41 Consumado o golpe e derrubado o governo, o jornal prosseguiu no mesmo tom. Cinco dias depois do Senado ter antecipado a maioridade do imperador, $O$ Brasil dizia que os simpatizantes do antigo governo tinham, antes de tudo, que pensar na salvação da pátria, na sustentação da ordem e da civilização, das instituições, reconhecendo que só lhes cabia aceitar os fatos consumados, esquecendo a ilegalidade do golpe. Esperava que os acontecimentos não produzissem "... reações nas províncias: reações sempre são perigosas, e no quadro atual poderiam causar aniquilação do Império". Em seguida, vaticinava que o novo governo mostrar-se-ia incapaz de pacificar a guerra civil no Sul. Por isso fracassaria. ${ }^{42}$

Foi o que aconteceu. Em março de 1841, os regressistas voltaram ao governo. Em novembro e dezembro do mesmo ano, recriaram o Conselho de Estado e reformaram o Código do Processo Criminal. Em 1 de maio de 1842, obtiveram do jovem imperador a dissolução da Câmara, que, de acordo com eles, teria sido formada a partir de eleições fraudadas e manipuladas. Os opositores, então, escolheram o caminho da revolução. Foram facilmente derrotados, militar, política e moralmente. Daí em diante, por um longo período, só lhes restou o caminho de uma espécie de "transformismo". Sua identificação, ou melhor dizendo, indiferenciação, com os conservadores, como notou Ilmar Rohloff de Mattos, mais do que uma indistinção da vida político-partidária no Segundo Reinado, indicava uma hierarquia e uma subordinação. ${ }^{43}$ 
44

HOLANDA, Sergio Buarque de. Do Império à República, Op. Cit., p.10; MATTOSO, Katia M. de Queirós. Bahia, século XIX. Uma província no Império. Rio de Janeiro: Nova Fronteira, 1992. p.254.

45

MELLO, Evaldo Cabral de. O Norte agrário e o Império - 1871-1889. Rio de Janeiro: Topbooks,

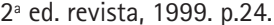

Para descrever e compreender mais detidamente a experiência histórica do Império do Brasil, tomarei como marcos o ano de 1847, ano de consolidação do sistema de governo parlamentar do Império, e a data da queda do regime, em 1889. Entre 1847, ano em que foi criado o cargo de Presidente do Conselho de Ministros, e 1889, sucederam-se 32 governos de gabinete no Império. Esses gabinetes eram formados por indicação do imperador, mas se relacionavam com as maiorias e minorias que se faziam e desfaziam na Câmara dos Deputados do Império. Essa relação entre gabinete e câmara podia ocorrer de duas formas. 0 imperador convocava um político, não necessariamente um deputado e normalmente um senador, que ele considerasse representativo da maioria parlamentar. Se este aceitasse, ele, então, formaria o gabinete. Na segunda forma, o imperador convocava um estadista para constituir o gabinete e esse, se não contasse com a maioria da câmara, a dissolvia, convocando novas eleições. Como o governo controlava as eleições, acabava por eleger uma câmara que o apoiasse. Alguns consideram esse parlamentarismo falso, se comparado ao modelo britânico que the servia de inspiração, ${ }_{1}^{44}$ ou "às avessas". ${ }^{45}$ Aliás, essa avaliação foi feita por políticos na própria época do Império, como no caso do famoso discurso conhecido como Sorites, proferido pelo senador Nabuco de Araújo, em 1868, quando o imperador chamou um conservador, o visconde de Itaboraí, para formar um novo gabinete, numa situação em que estes eram minoritários na câmara.

Não cabe aqui uma avaliação sobre a autenticidade ou não desse sistema parlamentar. 0 fato é que a escolha do gabinete nascia sempre em interação com uma câmara proporcional, representativa de eleições provinciais. Mesmo quando o gabinete era imposto à câmara, seu primeiro ato era dissolver a câmara e convocar novas eleições. Estas, por sua vez, eram manipuladas pelo governo que constituía assim uma nova maioria que o apoiava. A manipulação era feita através do controle exercido sobre juizes e delegados e em barganha com potentados locais, via de regra protegidos e protetores dessas mesmas autoridades locais. Tal manipulação, entretanto, não era absoluta, principalmente depois da reforma dos círculos eleitorais de 1855 . Sempre houve algum espaço, maior ou menor e até mesmo ínfimo, para a oposição. Contudo, a regra foi que, no geral, o governo não perdia eleição. Sem entrar em uma difícil discussão do quão realmente representativo - de quem? - era o sistema, buscando um hipotético valor representativo intrínseco num sistema parlamentar abstrato, o mais importante é examinar o quanto ele servia de canal de expressão e resolução para os conflitos políticos. Isso tanto no plano nacional quanto no plano provincial e local e na interseção entre estes planos.

Nesse sentido, o sistema funcionou, praticamente sem maiores tropeços, até a crise de 1868, e mesmo depois, até a crise final do regime. Esse era o sistema parlamentar no Império, e ele era expressivo de uma correlação de forças sociais e políticas, cuja presença, força e peso iam muito além do parlamento e das instituições políticas, ainda que deles não prescindisse. Essa correlação de forças, por sua vez, se desdobrava em dois ritmos entrelaçados: o ritmo mais lento das relações sociais, da hegemonia social de classe, e o ritmo mais rápido dos embates e arranjos políticos. A estabilidade do sistema político representava exatamente a condensação desses dois ritmos em um movimento em que a hegemonia social da classe 
senhorial se sobrepunha, limitava, conformava os conflitos políticos, delimitava sua arena, estabelecia suas regras.

Assim, não é por acaso que, tenha sido 1847, quando o tempo saquarema já ia avançado e o sistema dos partidos imperiais adquiriu uma feição mais estável, e não em outra época, que tenha sido criado o cargo de Presidente do Conselho de Ministros. Esse episódio refletia a maturidade do sistema. Refletia a hegemonia da classe senhorial e a direção moral e intelectual imprimida pelos conservadores, liderados também não por acaso pelos saquaremas fluminenses. Até o início da década de 1870, quando surgiu o partido republicano, ainda que este tenha permanecido amplamente minoritário até o final do regime, a câmara se organizou em dois partidos, o conservador e o liberal, demonstrando a estabilidade do sistema e a hegemonia senhorial. Se estes partidos não funcionavam como agremiações fundadas em programas doutrinários e políticos claramente diferenciados, nem por isso deixavam de ser distintos em termos de histórias, de estilos, até mesmo de valores. Apesar da existência de uma grande área movediça de interseção entre os partidos, onde havia desde a formação de acordos e alianças eventuais entre representantes de partidos distintos, até o bandeamento pura e simples de um partido para o outro, sua importância para o funcionamento e a estabilidade do sistema político não pode ser subestimada. Na dicotomia, tão caracteristica do século XIX europeu, entre ordem e liberdade, e que preponderou na cultura política imperial como um todo, o primeiro fator prevalecia amplamente sobre 0 segundo. A ordem era a condição da liberdade.

Nesse sistema representativo e parlamentar, determinadas bancadas provinciais pesavam mais do que outras. Mas, tão ou mais importante que o peso representativo das províncias, eram os mecanismos sociais e políticos que condicionavam quem as representaria. Quanto a esse aspecto, dois pontos devem ser salientados. Em primeiro lugar, o fato de que esses homens constituiam uma camada social específica de intelectuais, no sentido gramsciano do termo, oriundos da classe senhorial, a ela ligados ou por ela atraídos. Em segundo lugar, que na conformação dessa camada social de intelectuais como um grupo específico, o grupo dos estadistas imperiais, a Corte, enquanto espaço de sua formação, atração e aglutinação, desempenhou um papel fundamental.

Para melhor entender esse processo, analisarei a relação entre a Corte, a província do Rio de Janeiro e algumas províncias selecionadas, Minas Gerais, São Paulo, Bahia e Pernambuco, e a questão dos intelectuais na formação, construção e manutenção de uma hegemonia de classe. A escolha dessas províncias, e não outras, diz respeito ao peso que tiveram na vida política do império, como se verá.

Quanto aos intelectuais, como já esboçado acima, serão entendidos em sua função hegemônica, como dirigentes e políticos. Mais especificamente serão considerados, como estadistas imperiais, membros de uma elite - que chamaremos de elite dos estadistas imperiais - dentro da camada dos intelectuais: senadores e conselheiros de Estado. Ficam de fora da análise aqui proposta - mas não da configuração do campo intelectual na época, que fique claro - os literatos, jornalistas, formuladores de doutrinas, pensadores, etc. Para justificar esse estreitamento do foco de análise, vale lembrar que todos os presidentes do Conselho de Ministros eram senadores e a maioria, membro do Conselho de Estado. 0 Senado no Segundo Reinado não apenas havia mantido suas características restritivas 
46

ESCOSTEGUY FILHO, João Carlos. 0p, Cit., p.79 e ss.

47

Estou considerando como liberais o agrupamento político da Liga Progressista.
48

José Murilo de Carvalho assinalou a curta duração em média dos gabinetes do Império. Contudo, chamou a atenção para o fato de que os gabinetes conservadores foram mais duradouros, mantendo-se, em média, duas vezes mais que os gabinetes liberais ( $A$ construção da ordem e Teatro de sombras, Op. Cit., 2006, p.210-211). Podemos também considerar o período entre 1831, ano da abdicação de Pedro I, e 1847, a título ilustrativo. De 1831 a 1835, tivemos as Regências Trinas, provisória e permanente. Apesar de ter sido um período de compromisso, podemos considerar esse período como predominantemente liberal, dada a série de reformas empreendidas, culminando com o Adicional de 1834, e que seriam, na prática, anuladas pelo Regresso. A regência de Antônio Feijó, de 1835 a 1837, foi inequivocamente liberal. Após a breve regência provisória de Araújo Lima, um interregno de compromisso, sua regência de setembro de 1837 a julho de 1840, marca o início do período conservador por excelência. 0 golpe da maioridade e o governo que o segue, de julho de 1840 a março de 1841, por sua vez, são liberais. Os conservadores voltam ao poder e nele permanecem até fevereiro de 1844. Em seguida vem o quinquênio liberal, até maio de 1847, quando é criado o cargo de presidente do Conselho de Ministros. Ao todo, 11 anos de governos liberais e cinco de conservadores. Se somarmos ao cômputo entre 1847 e 1889, teríamos, entre 1831 e 1889, ainda um predomínio conservador: 32 anos de governo contra 26 dos liberais. Sobre a composição dos gabinetes imperiais, entre 1837 e 1878, ver NABUCO, Joaquim. Um estadista do Império. Rio de Janeiro: Topbooks, 1997. p.1167-1177. de câmara alta, como a vitaliciedade do cargo, previstas na constituição de 1824, como se tornara, principalmente, a partir do sucesso do Regresso conservador, o palco de atuação dos principais articuladores desse mesmo Regresso e, em seguida, do tempo saquarema. ${ }^{46}$

Tratava-se, pois, de uma elite restrita. Mais restrita ainda quando se considera o fato que alguns indivíduos ocuparam o cargo de Presidente do Conselho por mais de uma oportunidade. 0 pernambucano marquês de Olinda, por quatro vezes, sendo duas na condição de conservador e duas na de liberal. 0 baiano Zacarias de Góis, que havia pertencido ao partido conservador, ocupou o cargo na condição de liberal ${ }^{47}$ por três vezes. 0 visconde de Itaborai e o duque de Caxias, ambos fluminenses e conservadores, ocuparam o cargo por duas ocasiões.

0 ponto de partida da análise são duas observações bem simples e diretamente constatáveis nos próprios mecanismos formais de funcionamento do sistema: a distinção entre os partidos e a força representativa das províncias no que diz respeito à formação dos diferentes governos de gabinete, levando-se em conta o peso de cada província em termos do número de deputados de suas bancadas.

Quanto à distinção entre os partidos, dos 32 gabinetes formados de 1847 até 0 final do Império, os Liberais estiveram à frente de 17 deles, 0 que representa $53,1 \%$ do total, e os Conservadores, de 15 , representando $46,9 \%$. Contudo, em termos de tempo no poder, os Liberais, no todo, dominaram por 15 anos e cinco meses, mas os Conservadores o fizeram por 27 anos. Assim, estes detiveram o poder por $63,6 \%$ de todo o tempo, enquanto os Liberais o fizeram por 36,4\%. 0 tempo, apesar dos números, corrobora o argumento da hegemonia política conservadora. ${ }^{48}$

Qualifiquemos historicamente um pouco mais essa preponderância temporal dos gabinetes conservadores. Consideremos o domínio de cada partido por três grandes períodos da história do Segundo Reinado nos marcos propostos de 1847 e 1889: apogeu, de 1847 à queda de Zacarias, em 1868; declínio, do gabinete Itaboraí, em 1868, ao gabinete Paranaguá, em 1883; crise, do gabinete Dantas, de 1883, a 1889. Essas balizas são apenas indicativas, mas acredito que válidas. A primeira é a renúncia de Zacarias e a chamada de Itaboraí para formar um novo gabinete, quando os conservadores eram minoritários na câmara. Tratava-se de uma clara quebra das regras e abriu uma crise politica importante, que se desdobrou inclusive, um pouco depois, na criação do partido republicano. A segunda baliza, a posse do gabinete Dantas, é um pouco mais imprecisa. Dantas assumiu em 1883, dando continuidade a uma situação liberal que já vinha desde 0 início de 1878. Sua escolha representava as esperanças nele depositadas pela ala mais radical do Partido Liberal e por forças políticas de fora do parlamento - o movimento abolicionista, setores da imprensa, organizações mutualistas e beneficentes - que pregavam reformas e principalmente 0 avanço em direção à superação da escravidão, senão mesmo a abolição. A baliza proposta vale tanto pela a escolha de Dantas e as expectativas nele depositadas, quanto pela frustração dessas esperanças, já que Dantas, diante da oposição de conservadores e de setores dos liberais, pouco fez. 0 gabinete seguinte, do também liberal Saraiva, também não conseguiu aprovar a libertação incondicional dos escravos maiores de sessenta anos. Essa era uma reforma que os abolicionistas consideravam pífia, mas humanitária e por isso a apoiavam. Mesmo assim, não saiu. A reforma foi feita, somente quando foram admitidas compensações para os senhores de 
escravos, sob a forma trabalho que o liberto teria que prestar a seu antigo dono, à guisa de compensação, até completar a idade de 65 anos. Essa proposta foi formulada e efetivada pelo conservador Cotegipe que sucedeu Saraiva. Diante dessa frustração, o movimento abolicionista se intensificou e ganhou ainda mais as ruas e, logo, as senzalas. Toda essa discussão e movimentação políticas se deram em um quadro de crise, tanto política quanto social, crescente. Daí a escolha da posse de Dantas como marco de abertura do período de crise.

Vejamos, então, o tempo de poder de cada um dos partidos nestes períodos. No apogeu, os Conservadores estiveram no poder por $65,57 \%$ do tempo e os Liberais, $34,43 \%$. No período de declínio, enquanto os Conservadores dominaram por $59,43 \%$ do tempo, os Liberais o fizeram por $40,39 \%$. Finalmente, os Conservadores controlaram o governo por $69,77 \%$ do tempo, durante o periodo de crise, e os Liberais o fizeram por $30,23 \%$.

0 que se pode depreender dessas informações, tanto sobre o período geral, de 1847 a 1889, quanto especificamente em cada um dos subperíodos? Em primeiro lugar, que o fato dos Liberais terem formado mais governos, mas terem governado por menos tempo, pode significar que seus governos eram mais instáveis. Inversamente, e mais importante, que os Conservadores, como espero que a exposição a seguir ajude a corroborar, gozaram de maior coesão interna, devida principalmente à sua maior organicidade social, notadamente em relação à classe senhorial. Em segundo lugar, o fato de que os Conservadores tenham aumentado sua participação no período final de crise do Império pode significar não só que se aferravam à velha ordem escravista-imperial, como também, e por conta disso, que eram seu recurso mais embasado e confiável. É verdade que o Império caiu sob o governo Liberal do visconde de Ouro Preto, formado em 7 de junho de 1889 e que durou pouco mais de cinco meses. Mas isso não quer dizer tudo. Ouro Preto tentou administrar, sem sucesso, a enorme crise de legitimidade do regime em relação a sua base histórica de sustentação social, a grande propriedade rural escravista. Essa crise se abrira com o Treze de Maio de 1888. Em certo sentido, a tentativa de Ouro Preto de recompor a ordem imperial depois do Treze de Maio e sua frustração são o retrato condensado da fraqueza dos Liberais durante o Império.

Retrato, ou melhor, radiografia, que expõe sua falta de sólidas bases sociais nos grupos dominantes, mas também sua não penetração nos grupos subalternos, e, por isso, sua incapacidade crônica de promover reformas controladas e preventivas. Por um lado, os Liberais não viviam à altura de seu discurso. Por outro, eram também incapazes de conter as demandas que esse discurso ajudava a suscitar. 0 ministério Ouro Preto e sua queda, e com ela a do regime, foi um epílogo esperado. Um anticlímax. Na verdade, a sorte do Império foi selada quando o Partido Conservador se cindiu entre os que sucumbiram com e pela escravidão - Cotegipe e a bancada fluminense - e os que viram na prática que não havia transação possivel para além da abolição sem indenização - João Alfredo e os poucos que nele acreditaram.

Estabelecida a preeminência dos conservadores no governo do Império, analisemos, agora, a força representativa das províncias na formação dos governos centrais, que, como era de se esperar, era bastante diferenciada. 0 Quadro 1 mostra a distribuição dos presidentes de Conselho por suas provincias de origem. Um dos presidentes, Antônio Paulino Limpo de Abreu, o visconde de Abaeté, nasceu em Portugal. 
49

HOLANDA, Sergio Buarque de. Do Império à República, Op. Cit.
Quadro 1: Presidentes de Conselho por suas províncias de nascimento

\begin{tabular}{|l|l|}
\hline Província & N. de presidentes \\
\hline Alagoas & 1 \\
\hline Bahia & 12 \\
\hline Minas Gerais & 4 \\
\hline Pernambuco & 5 \\
\hline Piauí & 2 \\
\hline Rio de Janeiro & 5 \\
\hline São Paulo & 2 \\
\hline Portugal & 1 \\
\hline
\end{tabular}

Segundo Sérgio Buarque de Holanda, as quatro províncias com maiores bancadas na Câmara - Minas Gerais, Bahia, Pernambuco e Rio de Janeiro - dominaram a política do Segundo Reinado, constituindo o que ele denomina de uma tetrarquia. ${ }^{49} 0$ Quadro 2 estabelece essa relação.

Quadro 2: Bancadas e presidentes de Conselho pelas 4 maiores províncias

\begin{tabular}{|l|l|l|}
\hline Província & N. de deputados & N. de presidentes \\
\hline Minas Gerais & 20 & 4 \\
\hline Bahia & 14 & 12 \\
\hline Pernambuco & 13 & 5 \\
\hline Rio de Janeiro & 12 & 5 \\
\hline
\end{tabular}

A primeira constatação a se fazer sobre esses quadros é uma nãocorrespondência. Enquanto a Bahia, com 14 deputados, deteve 12 Presidentes de Conselho, Minas Gerais, apesar de seus 20 deputados, ficou apenas com quatro Presidentes. A segunda constatação é que Rio de Janeiro e Pernambuco, com bancadas semelhantes, 12 e 13 respectivamente, tiveram o mesmo número de Presidentes do Conselho, cinco. A questão de Minas merece um pouco mais de atenção e, aparentemente, coloca em dúvida a relação entre tamanho da bancada e ocupação do posto de Presidente do Conselho. Veremos adiante. Por outro lado, parece que estaria plenamente justificada a assertiva de Sérgio Buarque que, nos limites da tetrarquia por ele assinalada, o "baianismo" constituía a grande força política do período.

É preciso e possível, no entanto, examinar a questão em mais detalhes.

Um primeiro ponto a salientar é que Pernambuco e principalmente Bahia haviam formado, durante o período colonial, corpos burocráticos expressivos. Mesmo em decadência, a partir da segunda metade do século XVIII e durante o Império, continuaram a ser "celeiros" de quadros. Isto se deu tanto porque mantiveram relativa importância econômica, quanto porque dada sua densidade demográfica e a sedimentação social de seus grupos dominantes e mesmo médios, constituíram largas redes familiares, intra e supra-regionais. Essas redes familiares propiciavam a muitos de seus membros o acesso ao ensino superior em Portugal e, mais tarde, no Brasil, porta de entrada para alta burocracia governamental. Esse era um caminho importante para enfrentar exatamente as situações de decadência econômica e social que muitas dessas famílias enfrentavam. Com sorte, competência e habilidade, a carreira administrativa podia ser um meio de adquirir prestígio e 
Isto é, na mesma cidade do Rio de Janeiro, só que já durante os primeiros anos da República. riqueza através de prebendas, comendas, privilégios. Podia ainda dar oportunidades de bons casamentos em familias mais ricas e poderosas.

Esse caminho significou quase sempre um rumar para o centro de poder. Nesse sentido, um dado interessante a considerar é sobre o local de falecimento de todos os Presidentes do Conselho (Quadro 3). Nada menos que 15 deles faleceram na Corte e seis no Distrito Federal, ${ }^{50}$ perfazendo 21 , ou $65,6 \%$, do total. Somente dois dos 12 Presidentes nascidos na Bahia faleceram em sua província natal; nenhum dos cinco pernambucanos, assim como o único alagoano; apenas um dos quatro mineiros e um dos dois piauenses. 0 único português faleceu na Corte. Já todos os cinco Presidentes fluminenses e os dois paulistas faleceram em suas provincias de origem.

Quadro 3: Presidentes de Conselho por local de falecimento

\begin{tabular}{|l|l|}
\hline Província & N. de presidentes \\
\hline Corte ou DF & 21 \\
\hline Rio de Janeiro & 5 \\
\hline Bahia & 2 \\
\hline São Paulo & 2 \\
\hline Minas Gerais & 1 \\
\hline Piauí & 1 \\
\hline Alagoas & - \\
\hline Pernambuco & - \\
\hline Portugal & - \\
\hline
\end{tabular}

Como todos Presidentes de Conselho foram também Senadores e a maioria, Conselheiros de Estado, cargos vitalícios que representavam o ápice da carreira política, é natural que tivessem fixado residência na Corte. Nessa época, poucos retiravam-se da vida pública, o que fazia com que muitos fossem acometidos por doenças graves e viessem a falecer na Corte. Essa é parte da explicação, certamente. Mas, não se deve desconsiderar que sua fixação na Corte se devesse ao fato de terem sido absorvidos pelo centro de poder, ainda quando mantivessem vínculos com suas bases sociais em suas províncias de origem. Depoimentos de alguns estadistas imperiais, em seu próprio tempo de atuação ou em avaliações posteriores, de que serviam mais ao Império do que a suas províncias, vêm ao encontro dessa explicação. 0 fato de que todos os fluminenses e todos os paulistas, assim como dois dos quatro mineiros, tenham retornado a suas províncias de origem também pode ter um significado para além de que se tratavam de províncias mais próximas, geograficamente, da Corte. Tal proximidade dizia respeito também, e principalmente, às suas ligações com suas bases sociais, que também eram as principais bases do poder no Segundo Reinado: o núcleo da classe senhorial situado na Bacia do Paraíba do Sul, ou o que chamei, em outra ocasião, de Coração do Império, as províncias do Rio de Janeiro, São Paulo, Minas Gerais e a Corte..$^{51}$

A Corte era o centro político e administrativo do Império, o ponto de contato político, diplomático e cultural com o exterior, a mais importante praça comercial e financeira e o principal porto do pais. Por tudo isso, era o local de peregrinação para aqueles que queriam fazer carreira política, o mesmo se aplicando em termos de carreira intelectual e artística. 0 
Para uma sociologia histórica da sociedade de corte europeia, mas que, em muitos aspectos, pode ser estendida para o Brasil imperial, ver ELIAS, Norbert. A sociedade de corte. Rio de Janeiro: Zahar, 2001. Sobre os salões e a boa sociedade no Segundo Reinado, ver PINHO, Wanderley. Salões e damas do Segundo Reinado. São Paulo: Livraria Martins, 1942. sucesso e o prestígio dos estadistas dependia, em larga medida, do quanto se identificassem com o serviço do Estado, do Império e do imperador, cujo lócus era a Corte, e apenas secundariamente com sua províncias. Na Corte, em seus salões, nas antessalas dos palácios, nos bastidores da política, eram tecidas as amplas redes matrimoniais e de alianças inter-regionais. A Corte era o lugar onde se deixava de ser provinciano para se tornar cosmopolita. Um lugar onde se criavam melhores condições até mesmo para fazer política na própria província. ${ }^{52}$

Essa atração também se exercia sobre os estadistas oriundos da própria Bacia do Paraíba. Seu sucesso e prestígio, igualmente, dependiam do quanto se identificassem com o Império. Só que sua identificação com o Império e a Corte se dava através e abarcava a Bacia do Paraíba, onde, pelos laços familiares que mantinham e forjavam com os notáveis que mais poder, riqueza e prestígio tinham, construiam, conservavam e ampliavam sua redes de influência e poder. A ligação íntima da Corte com as demais províncias do Coração do Império e o peso que essas tinham, e não apenas a distância espacial menor, explicam porque os presidentes do Conselho, os Senadores e os Conselheiros de Estado delas oriundos mantiveram com elas laços mais estáveis e sólidos, inclusive fisicamente. 0 fato desses presidentes de Conselho terem morrido na província deveu-se certamente às circunstâncias da vida, mas diz alguma coisa. As circunstâncias da vida, como as da morte, podem ser fortuitas, mas poucas vezes desprovidas de sentido.

0 que há de comum nessas trajetórias e origens é que todas convergiram para, ou gravitaram em torno da região da Bacia do Paraíba e da Corte. Muitos provinham das próprias camadas de intelectuais estadistas propriamente ditos. Outros sobressaíam como expoentes de determinadas práticas e condições sociais mais locais ou regionais - fazendeiros, comerciantes, nobres e potentados locais. Os dois tipos de trajetórias combinaram-se de diversas formas, além de algumas vezes estarem encarnadas em uma mesma pessoa: por alianças, por casamentos, por redes de influência, etc. Esse conjunto de trajetórias e suas combinações, em sua convergência para a Corte e para o Estado imperial, constituíram a camada de intelectuais da classe senhorial. Como busquei demonstrar até agora, foi nas fileiras dos conservadores que esse processo ganhou forma e direção, ainda que não se restringisse a elas.

Algumas regiões e camadas sociais no alto da escala hierárquica da sociedade forneceram os quadros para a composição das fileiras conservadoras, e dos estadistas de uma maneira geral. Houve, em primeiro lugar, os que vieram do Antigo Regime, mais ligados à burocracia imperial, podendo ser portugueses ou brasileiros de origem. Ou ainda proprietários e comerciantes das zonas mais antigas, sedimentadas, em termos de ocupação do território, detentores de prestígio social, participantes e articuladores de redes mercantis, tanto comerciais propriamente ditas, quanto fundiárias, com propriedades escravistas voltadas para o mercado interno e externo.

No caso dos ocupantes de altos cargos na burocracia estatal, nascidos no Brasil e atuantes principalmente durante o Primeiro Reinado, além do exemplo clássico de José Bonifácio, podemos citar o baiano Miguel Calmon du Pin e Almeida, marquês de Abrantes, exemplo típico de um membro dos grupos superiores da sociedade baiana que se dirigiu para a Corte. Miguel Calmon nasceu em Santo Amaro, em 1796, e faleceu no Rio de Janeiro, em 1865. Formado em Coimbra, teve expressiva atuação em sua província no processo de Independência e no período do Primeiro Reinado. 
Vindo para o Rio de Janeiro, casou-se com Maria Carolina da Piedade Pereira Bahia, filha do barão de Meriti, grande proprietário de terras e escravos nessa região do Rio de Janeiro. Abrantes teve atuação destacada junto à corte imperial, além de importante partidário do Regresso. Participou dos ministérios de Bernardo Pereira de Vasconcelos, de 1837, na regência de Araújo Lima, e do primeiro ministério conservador depois da maioridade, de 1841, chefiado por Cândido José de Araújo Vianna, futuro marquês de Sapucaí, quando foi restabelecido o Conselho de Estado, foram aprovadas a Lei Interpretativa do Ato Adicional de 1834 e a Reforma do Código do Processo Criminal, que completaram a obra do Regresso.

Felisberto Caldeira Brant (1772-1842), marquês de Barbacena, é outro exemplo na mesma direção. Nascido em Mariana, formou-se em Portugal e veio com a Corte para o Rio de Janeiro. Atuante na independência, fez carreira na diplomacia, na administração e na política imperiais, tendo ocupado cargos de ministro, atuado no serviço diplomático e sendo eleito deputado na Assembleia Geral e no Senado.

Nestes casos, podemos dizer que essas trajetórias, se intimamente ligadas à construção do Estado imperial, precederam especificamente o momento de formação da classe senhorial enquanto uma classe nacional - quer dizer, uma classe que estabeleceu uma hegemonia nacional, não necessariamente uma classe presente, de forma homogênea, em todo o território nacional. Na raiz da formação da classe senhorial enquanto classe nacional está a trajetória do português José Clemente Pereira (1787-1854). Também ele um homem da independência e formado na burocracia da Corte. 0 que é interessante em seu caso, contudo, é como enraizou seus interesses na província fluminense. Formado em Coimbra, veio para o Brasil em 1815, ocupando cargos na burocracia estatal. Teve atuação intensa no processo de independência, durante o Primeiro Reinado e no período regencial. Foi ministro, senador e conselheiro de Estado. Casou-se com a viúva de um rico comerciante do Rio de Janeiro, Engrácia Maria da Costa Ribeiro e adquiriu propriedades rurais em Vassouras. Foi um dos articuladores do Regresso, emprestando seu apoio e prestígio a Bernardo Pereira de Vasconcelos. Sua enteada e herdeira, Maria Custódia Ribeiro de Oliveira, casou-se com Eusébio de Queirós, um dos membros da Trindade Saquarema.

Outra figura importante em termos das redes de riqueza, prestígio e de influência, construídas nas regiões sedimentadas da Baixada Litorânea e do Recôncavo da Guanabara na capitania e depois província do Rio de Janeiro, e que se entrelaçaram na afirmação do Estado territorial centralizado e logo nacional, foi José Carneiro da Silva (1788-1864). Sua trajetória adentrou o Império e, particularmente, o Segundo Reinado. Filho de portugueses já estabelecidos na região de Quissamã, onde nasceu, era proprietário rural e estabeleceu uma rede de influências, através dos casamentos de seus filhos, pela província e na Corte. José Carneiro tornou-se importante chefe político fluminense e recebeu o título de visconde de Araruama. Como ligação importante de sua família com o círculo de estadistas imperiais conservadores, vale lembrar o casamento de seu filho, Manuel Carneiro da Silva, segundo visconde Uruaí, com a filha de Luís Alves de Lima e Silva, o duque de Caxias.

Manuel Jacinto Nogueira da Gama (1765-1847), marquês de Baependi, foi ainda um exemplo mais completo do tipo de trajetória que articulou a origem em áreas sedimentadas, pode-se dizer mesmo no Antigo Regime, serviço na burocracia estatal, gravitação - em seu caso, 
PANG, Eul-Soo. In Pursuit of Honor and Power: Noblemen of the Southern Cross in NineteenthCentury Brazil. Tuscaloosa: University of Alabama Press, 1988. p.95-97; OLIVEIRA, Mônica Ribeiro. Negócios de familias. Mercado, terra e poder na formação da cafeicultura mineira. Bauru-SP: EDUSC, 2005 migração mesmo - em torno da Bacia do Paraíba e ligação com o café de Serra-Acima, de onde estabeleceu grandes articulações senhoriais e imperiais no decorrer do Segundo Reinado. Nasceu em São João del Rei e estudou em Coimbra. Teve atuação política intensa durante o Primeiro Reinado e a Regência. Foi deputado, senador e ministro do Império. Casou-se com a filha da baronesa de São Salvador dos Campos de Goytacazes, viúva de Brás Carneiro Leão, comerciante de grosso trato. Tendo se deslocado, como tantos outros para a região ainda relativamente pouco ocupada do Médio Vale do Paraíba, tornou-se proprietário rural em Valença. As vidas e os casamentos de seus filhos demonstram a tecitura de sua rede de influências em direção à grande propriedade cafeicultora e ao Estado. Brás Carneiro Nogueira da Costa e Gama (1812-1887), conde de Baependi, foi também proprietário de fazenda de café, tendo ocupado diversos cargos eletivos, por diversas vezes: vereador, deputado provincial e geral, senador. Sua filha, Francisca Jacinta Nogueira da Gama casou-se com Antônio Dias Coelho Neto dos Reis, grande proprietário rural na área de Campos e futuro conde de Carapebus. 0 outro filho do conde de Baependi, Manuel Jacinto Carneiro Nogueira da Costa e Gama (1830-1876), também foi fazendeiro. Foi deputado provincial. Morreu cedo e solteiro, não sem antes ter recebido o título de barão de Juparanã. Seu irmão, Francisco Nicolau Carneiro Nogueira da Costa e Gama (1832-1885), foi proprietário da fazenda Santa Mônica, em Juaparanã, recebeu o título de barão de Santa Mônica e casou-se com a prima, filha de Luís Alves de Lima e Silva, o duque de Caxias.

Das Minas Gerais, aqui propositadamente no plural, também vieram intelectuais da classe senhorial, tanto estadistas quanto intelectuais corporativos, isto é, com atuação no plano dos negócios, do local e do regional. A região já era bastante sedimentada e urbanizada a partir de sua história no século XVIII e contava com elites intelectuais formadas no serviço da Coroa, nas letras, nos estudos superiores. As Minas valiam também por sua densidade demográfica, seu mercado diversificado, suas elites agrárias e mercantis. No caso dos estadistas, já vimos Barbacena e devemos citar, é claro, Vasconcelos e Paraná. Ambos eram homens do meio, isto é, não pertencentes às altas esferas das elites burocráticas e econômicas, ainda que também não fossem gente da raia miúda.

Dos homens que foram para o Vale e formaram a classe senhorial em seu movimento molecular e corporativo, já falamos de Baependi e seus filhos. Podemos citar ainda Custódio Ferreira Leite, o barão de Aiuruoca (1782-1859), mineiro de São João del Rei que fez fortuna no Vale, ajudando e favorecendo também a fortuna dos sobrinhos, que viriam a dar origem aos Teixeira Leite, de Vassouras. Outro mineiro a fazer fortuna no Vale foi Estevão Ribeiro de Resende, futuro marquês de Valença (1777-1856). Formado em Coimbra, fez carreira como magistrado e político, no período pré-independência e no Primeiro Reinado. Vindo de uma família de proprietários rurais da região de Prados, foi proprietário rural em São Paulo e acabou se estabelecendo em Valença. Ele e seu clã tinham negócios e propriedades cafeeiras em Valença, Juiz de Fora e São Paulo. Tinham ainda ramificações com os Avellar de Vassouras, que estavam à frente da Casa do Pau Grande, cabeça de sesmaria na região de Vassouras. ${ }^{53}$ Ainda em Valença, estabeleceu-se o concunhado de Estevão Ribeiro de Resende, Joaquim José Pereira de Faro, primeiro barão de Rio Bonito (1768-1843). 0 clã dos Faro, com suas fazendas e negócios se espraiando a partir da região de Barra do Piraí, teve grande projeção na política provincial do Rio de Janeiro 
em meados do século. Nas décadas de 1850 e 1860, foram capazes de se sobrepor aos Teixeira Leite e aos senhores de Vassouras, trazendo o ramal da Estrada de Ferro Dom Pedro II para Barra do Piraí. ${ }^{54}$

As histórias de vidas e das redes familiares poderiam se multiplicar. Cada uma guardando sua própria especificidade. 0 que espero ter salientado, com a exposição feita até o momento é que, em sua tessitura única, essas trajetórias e histórias compunham em conjunto um todo mais amplo, que se estendia desde o mais alto escalão do governo do Império, no plano dos grandes estadistas, até o nível mais básico das fazendas, vilas e cidades do interior. Se não estavam dadas de antemão e se cada uma em sua singularidade trazia diferenças na composição da tessitura, essas trajetórias não deixaram de ser percursos determinados. Isto é, não deixaram de ser condicionados por circunstâncias constituidas por relações sociais mais amplas, objetivas, herdadas e estabelecidas de forma independente da vontade de seus protagonistas, sobre as quais, no entanto, suas ações repercutiam e atuavam transformando-as. Estas relações complexas, dinâmicas, variando de peso e importância em cada momento e situação históricos, implicaram e foram implicadas por diferentes capacidades de protagonismo social, das mais objetivas e coletivas às mais subjetivas e individuadas, consoante os momentos das relações sociais de forças, de acordo com as colocações teóricas de Trouillot e Gramsci que delineei no início desse trabalho.

Eul-Soo Pang, em trabalho que analisou a nobreza imperial, estabeleceu uma distinção entre uma gentry empreendedora, capitalista, de origem mais recente e vinda de baixo, mais ligada ao café e radicada no Centro-Sul, particularmente em São Paulo, contraposta a uma nobreza mais antiga, de origens no período colonial, mais ligada ao Norte e ao açúcar. No Rio de Janeiro, esta distinção poderia ser encontrada entre os grandes proprietários e nobres de Serra-Acima e do café, e aqueles da Baixada Campista e do açúcar..$^{55} \mathrm{Em}$ outro plano, ele também faz uma distinção entre os setores nobres e de elite moderadamente ricos, que estariam mais ligados à política e ao Estado patrimonialista, os mandarins, e aqueles mais ligados ao mundo econômico. Nobres e plantadores mais ricos confinariam a si mesmos na política local e regional, uma vez que os negócios mais dinâmicos da produção de café e açúcar requereriam maior atenção e presença direta. ${ }^{56}$ Haveria, assim, uma espécie de "divisão de trabalho" entre os nobres - e, por tabela, a elite de uma maneira geral - que se dedicavam mais aos assuntos do governo e os nobres e membros da elite mais apegados à administração dos negócios ligados ao mercado mundial capitalista, fossem estes plantações voltadas para a exportação e/ou para investimentos urbanos e financeiros. Os primeiros - os nobres e a elite voltados para a política - provinham, de um modo geral, dos setores sociais e das regiões mais tradicionais, das antigas famílias de grandes proprietários da colônia e da região Norte, ainda que não exclusivamente. Os segundos aqueles voltados para os negócios de ponta do café, dos investimentos em obras de infraestrutura e em finanças - constituiam uma nobreza e uma elite mais recente, uma espécie de gentry, em sua maior parte radicados na região Centro-Sul. Esses dois conjuntos de nobreza e de elite teriam duas visões de mundo distintas, ainda que tangencialmente fossem relacionados entre si. ${ }^{57}$

A distinção de Pang é sugestiva e sua constatação de que os setores de ponta da elite econômica circunscreveram sua atuação no âmbito dos negócios e da política local e regional é importante. Peca, contudo, ao 
trabalhar com a categoria estanque de elites, de forma demasiadamente calcada nas relações imediatas entre indivíduos, familias e suas posições sociais. Não se trata apenas de constatar a distinção entre os que se dedicavam primordialmente à política e aqueles que de dedicavam prioritariamente às atividades econômicas, mas de buscar estabelecer as condições sociais que marcavam tal distinção e relação. Numa palavra, trata-se de estabelecer as relações orgânicas entre um e outro setor: qual o peso de cada um, quais os planos de prevalência entre eles, que conjunto de interesses e práticas terminava por predominar e de que forma nestas relações; quais os movimentos de longo prazo e alcance, aqueles que conferiram a marca do período, e quais os de curto prazo, que responderam a questões mais conjunturais, dentro e a partir do quadro de tendências definido pelos primeiros movimentos, ainda que terminassem por afetá-los?

A distinção entre classe e intelectuais, conforme aqui se está procedendo e de acordo com Gramsci, permite verificar na análise histórica concreta essas relações e suas correspondentes capacidades - diríamos, hoje, agências: desde as mais corporativas e coletivas até as mais individuadas e políticas. Vejamos.

Como se pode depreender da própria exposição de Pang, os dois conjuntos de elite e nobreza - o político e o econômico - relacionavam-se e buscavam se relacionar entre si através de casamentos, compadrios e alianças. Esse movimento, entretanto, não era circular, mas tinha um claro sentido: uma elite, a política, gravitava para a outra, aquela ligada aos setores de ponta da economia. 0 caminho, é claro, era de mão dupla, mas se dava mais em um sentido do que no outro: membros da elite política casavam-se mais com os da elite econômica do que estes com os primeiros. 0 casamento do grande proprietário com o político ou o cortesão era uma possibilidade na tessitura de suas redes de parentela, riqueza e poder, mas estava longe de ser a mais importante e a mais frequente. Os clãs de grandes proprietários escravistas casavam-se primordialmente em seu próprio interior ou entre si. 0 contrário acontecia com a elite política, que buscava mais os casamentos - seus ou de seus descendentes e parentes - na elite econômica, sendo que alguns chegavam mesmo a migrar diretamente para esta última "elite". Nesse ponto, a palavra aparece entre aspas, uma vez que fica claro que as categorias de intelectuais, enquanto um grupo social de origens diversificadas, mas organicamente ligado a um Estado e de classe social mostram maior valor explicativo. No longo prazo e alcance, foram os interesses da grande propriedade escravista, mais especialmente da grande propriedade escravista da Bacia do Paraíba do Sul, que prevaleceram, umas vezes mais, outras vezes menos independente das intenções e motivações imediatas deste ou daquele agente. Os intelectuais eram assim representantes e, mais importante, dirigentes da classe senhorial, e não de si mesmos. Quando deixaram de sê-lo, na conjuntura pautada pela ascensão do movimento abolicionista e das lutas escravas, entre 1885 e 1888, 0 Estado imperial caiu.

Do ponto de vista das representações sociais, esta dinâmica entre a classe corporativa, isto é, os indivíduos, famílias, grupos, práticas e instituições que viviam, se afirmavam e se configuravam nos planos local e regional, e os grandes intelectuais, que ocupavam as posições de destaque no governo e na Corte, apresentava-se quase que como um percurso invertido: as atenções, os padrões de comportamento, os sinais de distinção, os signos de prestígio, tudo convergia para a Corte, o lugar da política e dos 
A expressão é de Ilmar R. de Mattos. Ver: 0 tempo saquarema, Op. Cit.

ALENCASTRO, Luiz Felipe. Vida privada e ordem privada no Império. IN:___ (org.). Histório da vida privada no Brasil. Vol.2. São Paulo: Companhia das Letras, 1997. p.23. intelectuais. A Corte era lugar de condensação dessas diversas trajetórias. Era o centro de peregrinação para as carreiras políticas, administrativas, militares e intelectuais. Essa posição Ihe dava a condição de destino e partida da via de mão dupla - da Corte para as províncias, das províncias para a Corte - pela qual se constituía a ação política hegemônica da Coroa enquanto partido gramsciano. ${ }^{58}$ Mesmo os que vinham de outras províncias, que não a do Rio de Janeiro, eram homens da Corte. Essa era a condição para adquirirem status, prestígio, títulos e, não menos importante, poder. Como senadores ou conselheiros de Estado, que já eram ou almejavam ser, haviam se estabelecido no Rio de Janeiro, ainda que mantivessem vínculos com suas províncias de origem. Na feliz frase de Luiz Felipe Alencastro, "forjou-se no Rio de Janeiro - capital política, econômica e cultural do país - um padrão de comportamento que molda o país pelo século XIX afora e o século XX adentro".59

III

Uma segunda questão a se ressaltar é quanto ao peso das províncias quando visto por partidos. Pode-se verificar que a força da Bahia diz respeito, mais ao partido liberal. Eram baianos 47\% de todos os Presidentes de Conselho liberais, enquanto que, entre os Conservadores, essa proporção, ainda que significativa, foi de $26,7 \%$. Já no que diz respeito ao peso da província fluminense, ele era maior entre os conservadores. Representantes fluminenses estiveram à frente de $33,3 \%$ de todos os gabinetes conservadores, ao passo que nunca estiveram no comando de gabinetes Liberais.

Mas, somente a origem dos presidentes do Conselho de Ministros não dá conta do peso fluminense nos governos conservadores. É importante considerar, a esse respeito, a base e a composição políticas dos gabinetes. Assim, os gabinetes conservadores do pernambucano Pedro de Araújo Lima, então visconde e futuro marquês de Olinda, de 29 de setembro de 1848, e o seguinte, do baiano José da Costa Carvalho, o também visconde e futuro marquês de Monte Alegre, de 6 de outubro de 1849, podem e devem ser considerados gabinetes fluminenses. Sua tônica foi dada pela famosa Trindade Saquarema - Joaquim José Rodrigues Torres, futuro visconde de Itaboraí, seu concunhado Paulino José Soares de Sousa, futuro visconde do Uruguai, e Eusébio de Queirós - que neles ocuparam as pastas da Fazenda, Justiça e Relações Exteriores. Os três, em 1848, comandavam os Conservadores fluminenses e, nessa época, passaram a liderar os conservadores nacionais. 0 fato de que Monte Alegre tenha sido sucedido exatamente por Rodrigues Torres, que, em 1844, havia sido eleito e escolhido Senador, foi a expressão e o corolário desse movimento.

A aliança com Olinda vinha desde a época do Regresso e de sua eleição para regente, em 1838, derrotando seu rival, o também pernambucano Holanda Cavalcanti, mas não perdurou. No início de década de 1860, o afastamento entre Olinda e a Trindade estava consolidado e ele bandeouse para as fileiras liberais. A instabilidade das relações entre Olinda e os conservadores fluminenses refletia, em parte, a instabilidade das disputas políticas pernambucanas, onde o domínio dos conservadores sobre os liberais nunca foi duradouro. A relação de Monte Alegre com os conservadores fluminenses, no entanto, foi mais estável. Ele havia se enraizado, através de dois casamentos junto a grandes famílias de proprietários rurais em São Paulo, o que facilitou sua aproximação com os fluminenses. Costa Carva- 
VIDIGAL, Geraldo. 0 marquês de Monte Alegre. Alvorecer de um estadista. São Paulo: Ibrasa, 1999. p.87-99; PANG, Eul-Soo. Op. Cit. p.116.
Iho casou-se com Genebra de Barros Leite, descendente tradicional família paulista e viúva do brigadeiro português Luís Antônio de Sousa, que, juntamente com seu irmão Francisco Antônio, acumulara grande fortuna na capitania. Este casamento consolidou a aliança de Costa Carvalho com o clã dos Sousa. Ou ao menos, com uma de suas alas, uma vez que diversos dos membros desse clã eram mais próximos às tradicionais famílias de São Paulo, como os Andrada, aos Vergueiro, aos Aguiar, que viriam a constituir as fileiras liberais em São Paulo. Costa Carvalho, pelo contrário, sempre fez política em comunhão com os conservadores do Rio de Janeiro, tendo sido um dos articuladores do Regresso. Enviuvado em meados da década de 1830, casou-se em segundas núpcias com Isabel de Sousa Alvim, sobrinha dos irmãos Luís Antônio e Francisco Antônio de Sousa, aprofundando seus laços de interesses com este grupo. ${ }^{60}$

Corrijamos, então, nossas cifras sobre a relação entre as províncias e os gabinetes imperiais desde a criação do cargo de Presidente do Conselho de Ministros, em 1847. Tirando Olinda e Monte Alegre do rol de gabinetes de fato pernambucanos e baianos, respectivamente, e os incluindo como gabinetes fluminenses, temos as seguintes proporções. Em termos gerais, a Bahia ainda mantém sua preeminência, contando com 10 gabinetes de fato, enquanto Pernambuco cai para quatro. Já os gabinetes de fato fluminenses sobem para sete e, se considerarmos, como devemos, o gabinete de 6 de setembro de 1853, organizado pelo visconde de Paraná, como de fato fluminense, estes sobem para oito.

A passagem do mineiro Paraná para o rol de presidentes do ConseIho de fato fluminenses não deve causar estranheza. Ele teve articulação decisiva para a vitória do Regresso, tanto no parlamento quanto em sua atuação como ministro. Exatamente nessa época - 1836 - ele se tornou proprietário de uma fazenda de café em Serra-Acima, na divisa das províncias do Rio de Janeiro e Minas Gerais. Honório, ligado ao mineiro Bernardo Pereira de Vasconcelos, foi figura expressiva no partido conservador fluminense e, como os saquaremas, governou a província. Ele não foi membro dos gabinetes de Olinda e Monte Alegre, mas sua atuação não deixou de ser crucial para seu êxito. Antes de tudo, sustentando-os no Senado e, mais expressivamente, quando em 1849, foi enviado a Pernambuco, como presidente da província, encarregado de sua pacificação e da repressão aos rebeldes praieiros após sua derrota militar. Em 1851, foi enviado em missão diplomática ao Prata, quando articulou as condições que propiciaram a intervenção militar vitoriosa contra Rosas e Oribe, iniciada no mesmo ano e concluída no seguinte. Por isso, foi agraciado com o título de visconde de Paraná. Em 1853, ele mesmo foi chamado a presidir o Conselho de Ministros, sucedendo o gabinete comandado por Rodrigues Torres. Por tudo isso, podemos considerá-lo um conservador fluminense.

No que diz respeito somente aos gabinetes Conservadores, que não esqueçamos controlaram o governo imperial pela maior parte do tempo (27 anos contra 15 dos Liberais), o efeito da correção é ainda mais drástico. Os oito gabinetes de fato fluminenses passam a representar pouco mais da metade, 53\%, de todos os Conselhos de Ministros conservadores, enquanto a Bahia, com três gabinetes, passa representar, ainda expressivos, mas bem menos, 20\%, e Pernambuco, com dois gabinetes, passa para 13,4\%.

E quanto às outras províncias, São Paulo e Minas, que contavam cada uma com um gabinete presidido por um político conservador nascido em suas terras? A primeira continua com sua contribuição proporcional de 
61

SALLES, Ricardo. As águas do Niágara. 1871: a crise da escravidão e o ocaso saquarema. In: GRINBERG, Keila e SALLES, Ricardo (org.). Op. Cit.. Vol.3, p.39-82; SALLES, Ricardo, Eo Vale era o escravo, Op. Cit, p.77-134.
$6,7 \%$, e a segunda deixa de ser contar com o deslocamento de Paraná para o Rio de Janeiro.

Houve gabinetes que podemos considerar mais propriamente ministérios da elite de estadistas imperiais. Isto é, gabinetes em que o Presidente do Conselho e alguns de seus ministros eram mais ligados à própria elite dos estadistas do que propriamente a grupos sociais regionais. Isto não quer dizer que estes presidentes ou seus ministros não tivessem ligações diretas ou indiretas com interesses regionais, muitas vezes com os interesses de grandes proprietários rurais escravistas. Não quer dizer, inversamente, que aqueles outros ministros que definimos como mais ligados a grupos regionais, não fossem eles também, na sua condição de intelectuais, membros da elite de estadistas. A tese é de que todos pertenciam a uma camada de intelectuais que, apesar de atravessada por contradições políticas, era orgânica à classe senhorial dos grandes proprietários escravistas, em especial à sua fração hegemônica do Vale e da Bacia do Paraíba. Por essa condição e por razões de carreira, circunstâncias da vida pessoal e convicção, alguns desses intelectuais eram menos diretamente ligados a grupos sociais regionais que outros. Ou, mais raramente, não o eram de forma alguma. Eram estes os casos dos homens de Estado oriundos da elite de estadistas imperiais.

Entre os liberais, podemos encontrar exemplos destes estadistas da Corte: 0 alagoano Cansanção de Sinimbu, que presidiu o conselho entre janeiro de 1878 e março de 1880; seu sucessor, o baiano José Antônio Saraiva, que permaneceu no cargo até janeiro de 1882, tendo novamente assumido a presidência do conselho entre maio e agosto de 1885; 0 mineiro Afonso Celso de Assis Figueiredo, visconde de Ouro Preto, o último presidente do conselho do Império, tendo assumido o cargo em junho de 1889. 0 senador e conselheiro de Estado Nabuco de Araújo, mesmo sem nunca ter ocupado o cargo de presidente do Conselho de Ministros, é outro exemplo de estadista dedicado ao serviço do Estado, quanto mais não seja pela sua biografia legada à posteridade por seu filho, Joaquim Nabuco. Nabuco de Araújo transitou das fileiras conservadoras para as liberais. $\mathrm{Na}$ discussão e votação da lei que decretava a liberdade do ventre da mulher escrava, entre 1867 e 1871, Nabuco de Araújo mostrou notável sua vocação de intelectual dirigente ao prever e argumentar que a reforma era necessária para evitar males maiores que certamente adviriam, mais cedo ou mais tarde, dado o isolamento internacional do Império como único país escravista remanescente no 0cidente. Antecipar-se e conduzir as reformas era a única e mais sábia maneira de manter ordem. Mas, o mais notável é que se Nabuco de Araújo expressou essa opinião durante o governo liberal (progressista) de Zacarias de Góes, que contava com seu apoio, ele a manteve quando a proposta passou para as mãos dos conservadores. A maioria de seus correligionários não fez isso e preferiu divergir e se opor ao governo. A postura de Nabuco de Araújo indicava a vocação de dirigente. ${ }^{61}$

Entre os conservadores, os intelectuais formados basicamente a partir da própria elite de estadistas, foram ainda mais expressivos. Dos gabinetes conservadores, podemos dizer que foram gabinetes de estadistas: 0 do português Limpo de Abreu, visconde de Abaeté, que presidiu o conselho de dezembro de 1858 a agosto de 1859, na esteira de ministérios que sucederam a Conciliação até a posse do liberal progressista Zacarias de Góis, em maio de 1862; o do baiano, igualmente adepto da conciliação, Ângelo Moniz da Silva Ferraz, barão de Uruguaiana, presidente do conselho 
SALLES, Ricardo. E o Vale era o escravo, Op. Cit., p.108-132. de agosto de 1859 a março de 1861, que descendia de uma tradicional família de comerciantes e financistas baianos; ${ }_{1}^{62}$ o do paulista José Pimenta Bueno, marquês de São Vicente, que assumiu o gabinete em sucessão a Itaboraí, entre setembro de 1870 e março de 1871, com a missão explícita e não cumprida, conferida pelo imperador, de fazer aprovar o projeto que determinava a libertação do ventre da mulher escrava.

Contudo, o caso do baiano José Maria da Silva Paranhos, que sucedeu Pimenta Bueno para cumprir a missão em esse último fracassara, é o mais significativo e merece que nos alonguemos um pouco sobre ele. Paranhos foi chamado pelo imperador, após ter desempenhado uma importante missão diplomática no Paraguai, tentando estabelecer as bases para uma paz favorável ao Império na região do Prata. A maneira como se saiu valeu-Ihe o título de visconde de Rio Branco. Ele vinha de família relativamente humilde na Bahia e cedo se mudou para a Corte, onde completou seus estudos na Escola Politécnica e na Escola Militar. Professor da Escola Militar e jornalista, aderiu aos liberais fluminenses e foi eleito para a Assembleia do Rio de Janeiro em 1845. Foi presidente interino da província e, em 1847, eleito deputado geral pela mesma. Com o advento da situação conservadora em 1848 e com a revolta dos praieiros, afastou-se da vida partidária, mas continuou exercendo suas atividades de jornalista. Apoiava discretamente a política do gabinete conservador no Prata e, 1851, foi convidado por Honório Hermeto Carneiro Leão para ser seu secretário em sua missão na região. Desde então, passou para os conservadores, mantendo-se ligado especialmente à ala fluminense do partido. Foi chamado para compor o ministério da conciliação com Paraná e depois o ministério de Caxias, em 1861. No ano seguinte, foi eleito e escolhido senador pelo Mato Grosso. No início da década de 1860, quando outros quadros do partido vindos do Norte, como o baiano Zacarias de Góis e o também baiano, mas radicado em Pernambuco, Nabuco de Araújo, iniciavam o movimento que os levaria aos liberais, Paranhos manteve-se fiel aos conservadores. Em 1866, foi escolhido membro do Conselho de Estado. Em 1868, foi chamado por Itaborai para compor seu ministério na pasta dos Negócios Estrangeiros.

Por seu prestígio, obtido em sua missão no Paraguai, e por sua convicção, recentemente adquirida, de que era necessário aprovar reformas que encaminhassem o fim gradual da escravidão, Paranhos foi chamado pelo imperador para fazer passar a lei que estabeleceria a liberdade do ventre da mulher escrava. Nas discussões sobre a questão no Conselho de Estado, em 1867, ele fora, no mínimo, relutante sobre a oportunidade de realizar tal reforma, ainda que reconhecesse, como quase todos os outros conselheiros, que, mais cedo ou mais tarde, o Império teria que assim proceder. Em 1871, contudo, estava convencido que era preciso passar a medida. A forte influência que sobre ele exercia o imperador e sua experiência no Paraguai, onde vivenciara, na situação extrema de uma guerra, o quanto a escravidão expunha o Império no cenário internacional, haviam mudado sua convicção. ${ }^{63} \mathrm{~A}$ evolução dos acontecimentos políticos no front interno, depois da virada de mesa de 1868, certamente também contribuiu para que Paranhos se convencesse da necessidade da reforma. A oposição radicalizava o discurso por reformas, entre elas a abolição gradual. 0 assunto era debatido abertamente, na imprensa e no parlamento. 0 manifesto do Centro Liberal, de 1869, redigido por Nabuco de Araújo, clamava por reformas como única saída para evitar a revolução. No ano seguinte, vinha a luz o Manifesto Republicano. Este, apesar de não tocar na questão da escravidão, propunha, no entanto, a substituição do regime. ${ }^{64}$ 
65 BRASIL. Falas do Trono. Brasília: INL, 1977. p.397. 66 CÂMARA DOS DEPUTADOS. Anais da Câmara dos Deputados, http://www2.camara.gov.br/, 1871, tomo IV, p.31-32.

67

Apud: NABUCO, Joaquim. Um estadista do Império, Op. Cit., p.842.
Paranhos, entretanto, teve que enfrentar forte resistência no seio do partido conservador, que, sob a liderança de Itaboraí e outros representantes diretos da Bacia do Paraíba, vinha se opondo à medida, a ponto de inviabilizar o gabinete São Vicente. Na Assembleia, a oposição vinha principalmente das bancadas que representavam as provincias cafeeiras e escravistas, Minas Gerais, Rio de Janeiro e São Paulo. Para se desincumbir da tarefa, Paranhos não relutou em se afastar de seus correligionários fluminenses. Articulou seu apoio entre os conservadores do Norte, região em que a grande propriedade rural, nesta altura, já não era tão dependente do trabalho escravo. No seu ministério, a pasta dos Negócios do Império foi ocupada por João Alfredo Correia de Oliveira, ligado aos interesses de Pernambuco. Na Fala do Trono, ocasião em que era exposto o programa do governo na abertura da Assembleia Geral do Império, em 3 de maio de 1871, a medida foi apresentada como sendo uma necessidade imediata. "É tempo de resolver esta questão". Os parlamentares, com prudência, saberiam "conciliar o respeito à propriedade existente com esse melhoramento social que requerem nossa civilização e até 0 interesse dos proprietários. ${ }^{65}$ $\mathrm{Na}$ tribuna, Rio Branco chegou a prognosticar que a resistência à reforma acirraria os ânimos e precipitaria a abolição imediata e sem indenizações. ${ }^{66}$ 0 projeto apresentado introduzia ainda a possibilidade que os senhores optassem por ficar com a tutela dos nascituros até a idade de 21 anos no lugar de receber uma indenização de 600 mil réis sobre o gozo presumido de uma propriedade futura. De nada adiantou. Os representantes dos escravocratas mantiveram-se intransigentes. Andrade Figueira, do partido conservador fluminense, ao contrário da argumentação de que se tratava da melhor maneira de enfrentar a inevitável crise da escravidão, acreditava que a lei seria a antessala da abolição, que se seguiria em breve. ${ }^{67}$

Apesar da forte oposição, Paranhos obteve sucesso em sua missão e a lei do ventre livre foi aprovada em 28 de setembro de 1871.0 mundo não acabou, como muitos apregoavam. 0 café continuou a ser produzido, os escravos continuaram a trabalhar e não vieram grandes convulsões sociais. Parecia até que possiveis tormentas futuras, previsiveis no quadro de isolamento internacional e de repulsa crescente à escravidão, haviam se dissipado diante da perspectiva de encaminhamento gradual e ordeiro da questão. Ao fim e ao cabo, o imperador e seu estadista haviam enfiado goela abaixo dos senhores o amargo remédio que consideram necessário para preservar a ordem imperial. 0 trabalho escravo ainda perduraria por mais quase 17 anos. Será que sem a lei ele teria acabado mais cedo, de forma abrupta e talvez violenta, como vaticinavam os defensores da reforma? Essa especulação retrospectiva é difícil. Em fins da década de 1870, numa avaliação oposta a essa especulação, muitos abolicionistas entenderam que a lei do ventre livre havia lançado a consciência antiescravista em um estado de letargia, da qual era preciso despertar. Os escravistas, por sua vez, passaram a brandir a lei como solução definitiva para a "questão servil", considerando novas reformas desnecessárias e perigosas.

Rio Branco permaneceu no cargo até junho de 1875, tendo comandado o mais longo gabinete do Império, não sem enfrentar crises. Em fins de maio de 1872, uma queda de braço entre Rio Branco e Paulino José, fiIho do visconde de Uruguai, e novo líder dos setores conservadores ligados à grande propriedade, terminou com a vitória desse último. 0 presidente do Conselho de Ministros, entretanto, pediu e o imperador acedeu a dissolução da Câmara. 
Mesmo assim, o partido conservador não rachou. Mas ele nunca mais teria o mesmo poder que tivera ao longo do Tempo Saquarema. A monarquia buscou, e em parte conseguiu, recompor suas bases sociais junto aos grandes proprietários. Quando Rio Branco caiu, foi substituído pelo igualmente conservador Caxias, a espada vitoriosa do regime, intimamente ligado à grande propriedade rural escravista do Vale. Seu prestígio, no entanto, não foi suficiente para compensar o vigor que cada vez mais faltava aos conservadores e à ordem imperial. Em 1879, a questão da escravidão foi reaberta, dessa vez não por pressão externa ou previdência de estadistas, mas pelo movimento abolicionista, que, logo se tornaria de massas e atingiria as senzalas.

É hora de voltar aos números, que a esta altura já deixaram de expressar meramente relações quantitativas. Constatamos que os gabinetes conservadores presididos por políticos identificados mais com a elite dos estadistas imperiais do que com bases socais e regionais especificas, ao todo, representaram um período de sete anos e dois meses. Eles estão compreendidos no conjunto e não alteram o total dos 27 anos de governos conservadores. Contudo, mais dois baianos, Silva Ferraz e Paranhos, devem ser retirados da cota de presidentes da Bahia. Os gabinetes baianos ficam, assim, dimensionados em oito, o mesmo número dos gabinetes substantivamente fluminenses. Ainda um número expressivo, mas não tanto quanto os 11 iniciais. 0 alcance social e político dessas constatações é muito mais importante.

Em primeiro lugar, salta aos olhos o papel que a Corte desempenhou como polo de formação, através de um processo de atração e aglutinação de intelectuais. Esse papel aglutinador e formador se dava qualquer que fosse a origem dos estadistas: intelectuais oriundos de configurações regionais, normalmente articuladas com a grande propriedade rural escravista, o comércio, as finanças, a burocracia governamental; letrados de um modo geral; ou, finalmente, provenientes de uma camada social específica de intelectuais, a elite dos estadistas imperiais. Em graus variados, os intelectuais das províncias mantiveram seus vínculos com suas bases sociais e políticas de suas províncias. Esse fato se processava tanto pelos mecanismos políticos formais das eleições proporcionais, quanto pelo jogo de influências e interesses. Contudo, na Corte, representavam o Império, tanto por convicção, adquirida no processo de sua formação, quanto por compreenderem que o Império não era uma abstração, mas tinha uma força material, econômica, social e política, própria.

E neste ponto e em segundo lugar, fica, mais uma vez, evidente 0 peso diferenciado da província do Rio de Janeiro entre as demais províncias. A força material do Império advinha de seus vínculos com uma base territorial e social específica, a região da Bacia do Paraiba e sua classe senhorial, configurada crescentemente, a partir da segunda década do século $\mathrm{XIX}$, em torno da província. Essa base territorial foi o café e, mais ainda, a escravidão. É importante salientar, contudo, que os vínculos entre o Império e suas bases materiais não se impuseram naturalmente, por mera força gravitacional exercida pelo poder econômico e pelo poder político e social que este confere aos grupos que o detêm. Tais vínculos foram construídos pelo partido conservador, que se forjou nessa construção. Nesse processo, foi fundamental a atuação da facção fluminense do partido, em coopera- 
Já citei o caso do conservador Manuel Vieira Tosta, marquês de Muritiba, nascido na Bahia, que fez carreira política no Estado e que casou seu filho com a neta do barão de Capivari, grande proprietário rural do Vale. Também o baiano Zacarias de Góis, liberal, que casou a filha Ana Carolina com Francisco Martins Esteves, também um grande proprietário rura fluminense em Valença.

\section{9}

Sobre Cotegipe e o gabinete de agosto de 1885 na crise do Império, ver NASCIMENTO, Carla Silva do. 0 barão de Cotegipe e a crise do Império. 2012. (Dissertação de Mestrado). Universidade Federal do Estado do Rio de Janeiro, Rio de Janeiro, 2012. ção com outros grupos regionais próximos: os mineiros e os paulistas, com quem muitas vezes se misturava, por laços de alianças, compadrios, casamentos e interesses, porque partilhavam da mesma base de sustentação social e econômica no café, na plantation escravista, nos grandes negócios financeiros; os baianos e os pernambucanos, com quem também mantinha laços semelhantes, mas não se misturava. Baianos, pernambucanos e outros ligaram-se, é claro, por compadrio, amizade, casamento e interesse a grandes familias de proprietários rurais, comerciantes estadistas da Bacia do Paraiba, mas, na maioria das vezes, quando o fizeram já haviam sido atraídos para a Corte. ${ }^{68}$

0 gabinete conservador do barão de Cotegipe, que durou de agosto de 1885 a março de 1888, é exemplar a respeito de tudo isso. Cotegipe era um membro calejado da elite de estadistas quando foi chamado para compor o governo em substituição a uma situação liberal que se mostrara incapaz de passar mais uma reforma em relação à questão da escravidão. Apesar de suas atividades políticas na Corte, Cotegipe não se afastara de sua província de origem, a Bahia. Lá possuía um engenho de açúcar no Recôncavo, casara sua filha e mantinha intensas articulações políticas. Chamado pelo imperador, sua principal tarefa era encaminhar reformas emancipacionistas que, por um lado, amainassem a maré montante do movimento abolicionista e, por outro, fossem palatáveis aos grandes fazendeiros e seus representantes escravocratas. A versão da lei que libertava os escravos com 60 anos ou mais que fez aprovar - onde seus antecessores liberais Dantas e Saraiva haviam patinado - mostrou que isso era impossivel. A cláusula que previa a compensação dos fazendeiros pelo trabalho do emancipado até que completasse 65 , que já não era grande coisa em termos de impacto sobre a escravidão real, dobrou os fazendeiros, mas frustrou as expectativas abolicionistas. A partir de 1885, o movimento só fez se radicalizar e buscar apoio nas ruas e nas senzalas.

0 ministério montado por Cotegipe era em tudo alinhado com os interesses dos senhores de escravos da Bacia do Paraiba. Contava, entre seus seis ministros, com três políticos ligados à classe dominante das províncias cafeicultoras: Antônio Prado, fazendeiro e senhor de escravos de São Paulo; o fluminense Francisco Belisário de Soares de Souza, ex-presidente do Banco do Brasil; e o mineiro Joaquim Delfino Ribeiro da Luz, ligado aos fazendeiros da província. No parlamento, não sem atritos, podia contar com o apoio dos representantes fluminenses Paulino José Soares de Sousa, filho homônimo do saquarema visconde do Uruguai, e Andrade Figueira. Com eles e com o Vale, Cotegipe foi até o final. Apeado do governo em março de 1888, dada sua recusa em encaminhar uma lei da abolição, Cotegipe voltou ao Senado onde se juntou imediatamente a Paulino e Figueira bradando contra a preparação e a aprovação da abolição imediata e sem indenizações. ${ }^{69}$

A análise da atuação de Cotegipe à frente de seu ministério e diante da Abolição mostra, de forma cabal, que o puro e simples alinhamento numérico dos governantes com suas regiões de origem e mesmo de articulação de sua base político-parlamentar é insuficiente para dar conta da configuração de poder ao longo da maior parte da história do Segundo Reinado. Não seria correto "corrigir", como vimos até agora fazendo, a filiação do gabinete Cotegipe. Ele era um baiano, por origem, por articulações político-partidárias e por interesses pessoais, familiares e de grupo de influência imediata. Mas seu governo esteve longe de representar somente esses interesses. 
HOLANDA, Sérgio Buarque de. Do Império à República, Op. Cit. p.140; NEEDELL, Jeffrey. The Party of Order, Op. Cit., p.279.
Se o compararmos ao gabinete de outro baiano, Rio Branco, temos um interessante paradoxo. 0 baiano Rio Branco, radicado no Rio de Janeiro e que fizera sua carreira sob os auspícios dos saquaremas, contrariou seus interesses, arrostou sua oposição e impôs uma lei que, só mais tarde, diante de ameaças maiores, eles iriam defender. 0 baiano com interesses enraizados em sua província, Cotegipe, governou com e para os grandes proprietários do Vale do Paraíba e seus representantes. 0 fato de Cotegipe ter sido ele mesmo proprietário rural e senhor de escravos, e Rio Branco não, aparentemente ajudaria a explicar o paradoxo, mas essa é uma explicação simplista e reducionista, além de absolutamente personalista. Ampliar um pouco mais a análise de suas redes de relações imediatas, pessoais, econômicas, políticas, etc. também não resolve a questão, ainda que enriqueça nosso conhecimento sobre a vida desses homens. A parte mais substancial da explicação do paradoxo encontra-se, como é óbvio, nas distintas circunstâncias históricas em que Rio Branco e Cotegipe governaram. Esse fato, entretanto, tende a ser subestimado por análises por demais concentradas em micro-descrições sociológicas ou antropológicas sobre redes e estratégias de personagens e grupos específicos. Os governos de Rio Branco e Cotegipe, ainda que num mesmo espaço estrutural que vinha se transformado, expressaram e atuaram sobre diferentes correlações de forças políticas e sociais, em meio a diferentes tendências culturais, situações econômicas, contextos internacionais, etc. 0 simples fato de que um governou depois do outro, isto é, tendo a experiência, direta ou indireta, do governo anterior, conta como parte da explicação. 0 próprio Cotegipe, ainda que, tendo sido convidado, se recusara a participar do gabinete de Rio Branco, mas não deixara de prestar seu apoio discreto à reforma do ventre livre. ${ }^{70}$ Ele, no entanto, em 1885, diante do movimento abolicionista e da crescente onda de fugas e revoltas e escravas em algumas regiões, estava com os escravocratas. Esse episódio é importante no sentido de ressaltar que, independente dos posicionamentos individuais, dessa ou daquela disputa e inflexão, terminou por prevalecer, entre os conservadores, a continuidade orgânica com a classe senhorial e com o Estado imperial, na feição que este tomou no Segundo Reinado. Foi esta continuidade orgânica que, a despeito de suas flexões internas, que forneceu a base para a maior coerência e unidade política do partido.

\section{IV}

Somente a dimensão geográfica e administrativa, em termos das províncias e do peso direto de suas representações parlamentares, é insuficiente para dar conta do conjunto de articulações econômicas, sociais, políticas e culturais que sustentaram o poder imperial. E o são mais ainda as explicações que se restringem à formação de redes familiares e de compadrio como as bases desse mesmo poder. 0 poder imperial foi o poder da classe senhorial. Esse poder, tanto em sua face de dominação, quanto em sua face hegemônica, assentou-se sobre as regiões do café, situadas no Coração do Império: a província do Rio de Janeiro, a Corte e a região em torno, abrangendo partes da província de Minas Gerais e a província de São Paulo. Ali pontuaram grandes fazendeiros escravistas, comerciantes, capitalistas e comissários, governantes que com eles faziam negócios e os financiavam, e as redes de políticos e magistrados que se articulavam através deles. Foram esses homens que, na política, fizeram as coisas acontecerem, exemplifi- 
71

GOUVÊA, Maria de Fátima Silva. 0 império das províncias. Rio de Janeiro, 1822-1889. Rio de Janeiro: Civilização Brasileira, 2008; LENHARO, Alcir. Op. Cit. MATTOS, IImar R. de. O Tempo Saquarema, Op. Cit.

72

TAUNAY, Affonso de E. (1939-43). História do café no Brasil. 15 Vols. Rio de Janeiro: Departamento nacional do Café, 1939-1943, Vol.5, p.164. cando a terceira capacidade de atuação humana na História que Trouillot distinguiu, como sujeitos propriamente ditos. Suas atuações e articulações não se esgotavam nelas mesmas. Dependeram do sucesso que obtiveram nos embates com as ações e articulações de outros homens. Em primeiro lugar, nos embates mais importantes, mas nem sempre os mais urgentes, contra aqueles que eram a fonte de seu poder e, ao mesmo tempo, seus maiores inimigos em potencial, os escravos. Em segundo lugar, dos embates contra aqueles que, dotados da mesma vocalidade e capacidade de atuação política, eram, nesse sentido, seus pares: seus aliados e adversários políticos, outros fazendeiros, comerciantes, capitalistas e comissários, governantes, etc. Isso tanto no plano local, como nos planos regionais, nacional e internacional.

0 sucesso ou fracasso nesses embates, ainda que assim pudesse parecer, não repousava no acaso. Quem ganhava e quem perdia dependia em larga medida de quem tinha melhores condições de vencer; de quem entendesse melhor e estivesse mais bem posicionado em relação às condições históricas mais favoráveis, tanto em termos objetivos, materiais e culturais, quanto em termos subjetivos, morais e intelectuais. Esse conjunto de condições, onde nunca umas podiam ser isoladas das outras, era, por sua vez, resultou das lutas e embates anteriores, mas envolveu também processos históricos de mais longa duração, abrangência, sedimentação e duração. Alguns desses processos históricos atuaram mais diretamente e com maior impacto na vida política, como os mercados de bens, capitais e mão-de-obra. Outros processos atuaram mais indiretamente e com impacto mais lento: a geografia, as tradições, as línguas, culturas e instituições. Uns e outros foram as condições, as bases sociais, do poder que esses homens exerceram, em um conjunto de relações reciprocas, uns sobre os outros.

Nesta altura, creio já não ser necessário expor ou buscar mais argumentos empíricos no sentido de ressaltar o peso diferenciado da província do Rio de Janeiro e dos conservadores na configuração do poder imperial. Toda a argumentação aqui desenvolvida foi no sentido de que esse peso derivou das relações econômicas, sociais e políticas estabelecidas entre a província e a Corte que giraram em torno da escravidão, da classe senhorial e da economia cafeeira. Cabe agora considerar como essas condições se estabeleceram e foram operacionalizadas por determinados agentes, os saquaremas e outras lideranças conservadoras articuladas em torno do Coração do Império, ao longo de um período histórico delimitado.

Como demonstrou Maria de Fátima Gouvêa, a partir da trilha aberta por Alcir Lenharo e llmar Rohloff de Mattos, o Rio de Janeiro, gozava não apenas da proximidade física com a Corte, centro do poder central.. ${ }^{71}$ Essa proximidade era principalmente orgânica: econômica, social, política e cultural. Ela se formou e foi construida ao longo das três primeiras décadas da história do Império do Brasil e foi propiciada pela expansão do café, o recrudescimento da escravidão, transformando o que até então era a hinterlândia do porto e da praça do Rio de Janeiro em um território ao qual essa mesma praça e porto passaram a se subordinar. Em 1828, os rendimentos do governo oriundos do café na futura província do Rio de Janeiro já ultrapassavam aqueles do açúcar. ${ }^{72}$ Num movimento de inversão, o porto e a praça passaram a responder aos fluxos econômicos que se originavam no território a partir da expansão do café.

A demanda internacional pelo café e a posição de quase monopólio no fornecimento do produto que os fazendeiros gozavam faziam com que 
73

Tese que, corrente na historiografia brasileira atual, foi expressa pela primeira vez por FRAGOSO, João e FLORENTINO, Manolo. 0 arcaísmo como projeto: mercado atlântico, sociedade agrária e elite mercantil em uma sociedade colonial tardia: Rio de Janeiro, c.1790 - c. 1840 . Rio de Janeiro: Diadorim, 1993.

74

Prefiro usar a expressão, em parte paradoxal, aristocracia aburguesada à noção de gentry, utilizada por Eul-Soo Pang, em In Pursuit of Honor and Power, trabalho que inspirou boa parte dessas reflexões, para designar a mentalidade e a inserção dos grandes fazendeiros ou plantadores escravistas do Brasil do século XIX no sistema internacional do capitalismo histórico. Pang considera que os grandes proprietários escravistas do XIX, base da nobreza imperial, se caracterizariam por serem uma elite formada a partir de uma "agricultura capitalista", isto é, um sistema econômico baseado não apenas na propriedade privada dos fatores de produção, tais como a terra, o trabalho, os instrumentos de trabalho, mas que também institucionalizava os processos de maximização de lucros através do risco calculado desses fatores de produção, inserido no sistema-mundo capitalista. Op. Cit., p.6.

75

PARRON, Tâmis. Op. Cit. seus negócios fossem extremamente lucrativos. É esse fato - e não uma propensão atávica para o arcaísmo do Antigo Regime ${ }^{73}$ - que, com a perspectiva de aumento de lucratividade, acompanhada da redução de riscos econômicos, financeiros e políticos, explica por que muitos comerciantes migraram para o negócio das fazendas do café. Economicamente, os negócios dos grandes fazendeiros eram mais avultados, diversificados, complexos e mais seguros e lucrativos do que o comércio e o rentismo urbano. Até porque estes se encontravam em posição relativamente mais fraca, enquanto setores intermediários entre a produção e o mercado externo, na feição que este tomava com o desenvolvimento do capitalismo no século XIX, se comparados com a situação do século XVIII. Era a força de seus negócios rurais que permitia aos grandes fazendeiros e senhores de escravos diversificarem sua fortuna, adquirindo joias, títulos e outros ativos financeiros. Era essa pujança econômica e sua posição social de grandes proprietários, de terras e de homens, que conferiam uma base sólida ao prestígio que gozavam, transformando-o diretamente em poder efetivo. 0 espírito empresarial de busca do lucro era, assim, parte constitutiva do éthos senhorial. A honra da nobreza era almejada e concedida pelo serviço ao Estado e pela benemerência que a riqueza propiciava. Era uma nobreza de honra e de poder, da civilização e do progresso, condição que nem todos conseguiam. Desse modo, a classe senhorial se constituiu numa aristocracia em que riqueza, posição social, poder político e, em menor grau, prestígio junto à dinastia e origem familiar foram os sinais e os fatores de status. Uma aristocracia aburguesada, que teve, em Napoleão, seu mito e seu fantasma. ${ }^{74}$

Sem a compreensão desse quadro e do poder da classe senhorial, que não se aplica aos proprietários rurais escravistas genericamente, mas aos cafeicultores da Bacia do Paraiba e a alguns outros poucos setores em outras províncias, não se pode, por exemplo, explicar um fato como a extinção efetiva do tráfico internacional de escravos em 1850, nem, anteriormente, sua reabertura na prática por volta de 1835, após sua primeira extinção legal de 1831. Este último acontecimento escorou-se muito mais na pressão, no apoio e nos anseios dos fazendeiros, do que na vontade dos comerciantes e traficantes. ${ }^{75}$ Já a proibição do tráfico em 1850 foi fruto direto da pressão inglesa, que se intensificara e vinha num crescendo, ameaçando mesmo chegar a uma situação de beligerância, desde 1845 . Contudo, o fato de que a cultura cafeeira na Bacia do Paraiba como um todo já superara sua fase de implantação e estava consolidada, sem depender criticamente do aporte de novas levas de escravos africanos, na escala que até pouco tempo havia sido necessária, permite entender por que os fazendeiros aceitaram e por que o governo saquarema cedeu às pressões diplomáticas e armadas britânicas. Como eles fizeram questão de dizer, e os fazendeiros entenderam perfeitamente, a proibição do tráfico não visava acabar com a escravidão. Isso não quer dizer que ambos, principalmente, os fazendeiros tivessem se convertido à argumentação de que o tráfico, além de imoral, não era um bom negócio. Não há, a não ser como clara resposta à pressão insuportável do ingleses, qualquer indício que, deixadas as coisas como estavam, o governo teria a iniciativa de efetivamente colocar em prática e os fazendeiros fossem aceitar a proibição do tráfico.

Isso evidencia os processos econômicos e sociais mais amplos de formação da classe senhorial que condicionaram e, ao mesmo tempo, foram afetados pelos acontecimentos. A classe senhorial formou-se e se espalhou pela Bacia do Paraiba, no rastro da transformação das fazendas já existen- 
SCHNOOR, Eduardo. Das casas de morada às casas de vivenda. In: MATTOS, Hebe \& (org.), Resgate. Uma janela para o Oitocentos. Rio de Janeiro: Topbooks, 1995; ANDRADE, Marcos Ferreira de. Casas de vivenda e de morada: estilo de construção e interior das residências da elite escravista sul-mineira - século XIX. Anais do Museu Paulista, v.12, n.01, jan.-dez., 2004, p.91-128. MARQUESE, Rafael de Bivar. 0 Vale do Paraíba cafeeiro e o regime visual da segunda escravidão: o caso da fazenda Resgate. Anais do Museu Paulista, São Paulo, v.18, n.1, jan.-jul, 2010

77

GOUVÊA, Maria de Fátima. O Império das províncias, 0p. Cit., p.17-69.

78

SALLES, Ricardo. E o Vale era o escravo, Op. Cit. tes ou na abertura de novas fazendas; na transformação das casas de morada em casas de vivenda; na conformação de um estilo de vida próprio e do que Rafael Marquese chamou de regime visual da segunda escravidão. ${ }^{76}$ Essa formação não se deu apenas a partir daquilo que Gramsci denominou de transformações moleculares, no plano da difusão e condensação de práticas sociais, das formas de dominação e de exploração do trabalho, do tecer de redes familiares, de compadrio e de aliança, e da consolidação dos mecanismos de poder local. A classe senhorial, enquanto uma relação social escravista e como uma formação social dotada de habitus e éthos próprios, estabelecida em um território e inserida em um tempo histórico, expandiu-se por obra da ação de seus intelectuais na frente da grande política, que imprimiram uma direção moral e intelectual ao processo de construção do Estado imperial na feição que este adquiriu no Segundo Reinado. A ação desses homens se deu em dois movimentos concomitantes: seu assenhoramento do governo da província mais importante, econômica e politicamente, da Bacia do Paraíba e a direção moral, intelectual e prática que estabeleceram sobre o Estado imperial. Sem essa ação específica, concreta, singular, particularizada em sujeitos de carne e osso, individuais ou coletivos, o movimento de formação e expansão molecular da classe senhorial, processo eminentemente econômico, social e cultural coletivo, não se consolidaria.

Por outro lado, sem o peso material, em parte inconsciente e espontâneo desse movimento de expansão, molecular, em que surgiam, para onde se dirigiam e onde buscavam sustentação, a ação desses sujeitos políticos careceria de organicidade social, da coerência, unidade de propósitos, efetividade que de fato tiveram. Os processos de hegemonia corporativa e política, nos níveis locais e provincial, foram concomitantes e interligados ao processo de estabelecimento da hegemonia política geral, que se processou nos planos da Corte e do Império. ${ }^{77} \mathrm{E}$ aqui, não se está falando hipoteticamente, mas historicamente, isto é, compreendendo e explicando como de fato as coisas se passaram, e não como poderiam ter sido, mas não foram. É esse duplo processo que estou chamando das duas faces da hegemonia senhorial: a hegemonia de classe e a hegemonia política saquarema. Duas faces porque, se por um lado, podem e devem ser analiticamente distinguidas, por outro, não podem ser historicamente separadas. Sem a ação e sem a direção dos saquaremas, num tempo histórico determinado, e sem a ação de outros que a mantiveram, adaptaram e expandiram, em circunstâncias históricas distintas e posteriores, não haveria classe senhorial enquanto processo histórico complexo, real, com alcance muito maior que a mera existência corporativa de grupos de senhores dispersos.

Nessa movimentação histórica complexa reside a especificidade não apenas da província do Rio de Janeiro e da Corte, como centro político do Império, mas igualmente das províncias de Minas Gerais e São Paulo, conformando a região social da Bacia do Paraíba, ou o Coração do Império. ${ }^{78}$

Do ponto de vista das grandes vertentes de interpretação sobre a formação do Estado imperial, as diferenças em relação à tese do patrimonialismo e do clientelismo, atualizada em sua versão das redes familiares de interesse, e em relação à tese das elites regionais, atualizada em sua versão "federalista", devem estar bem claras. 
CARVALHO, José Murilo de. A construção do ordem e Teatro de sombras, Op. Cit., p.211 e p.352.
80

SALLES, Ricardo. E o Vale era o escravo, Op. Cit., p.177 e ss., p. 188
Resta considerar a tese da elite política centralizada de José Murilo de Carvalho. Cabe, em primeiro lugar, ressaltar a proximidade em termos de problemática tratada. Tanto para José Murilo de Carvalho quanto para Ilmar Rohloff de Mattos, aqui tomados como paradigmáticos de uma tradição que se quer retomar, há uma questão a ser enfrentada e que não é formulada e, muito menos, respondida a partir da mera descrição dos fatos. Essa questão é a da formação do Estado nacional no período imperial e de sua relação com as estruturas econômica, social, cultural e política do Brasil, ou da América portuguesa, a partir das últimas décadas do século XVIII e ao longo do século XIX.

Em segundo lugar, trata-se de assinalar a proximidade e a divergência que a tese da elite política independente, mesmo que em uma relação dialeticamente ambígua com a classe dominante de grandes proprietários escravistas, e a tese dos intelectuais orgânicos dessa mesma classe guardam entrem si. 0 próprio José Murilo, ainda que reconhecendo que, em sua maioria, os membros da elite política provinham de setores da classe dominante, assinalou a impossibilidade de considerar a elite política imperial como uma camada de intelectuais orgânicos no sentido gramsciano do termo. ${ }^{79}$

Já na tese ilmariana, aqui seguida e aprofundada, trata-se de entender a autonomia e a dependência dos intelectuais nos quadros de sua organicidade em relação à classe senhorial, neste primeiro momento tomada como mera posição comum objetiva no campo das relações imediatas de produção. Desse modo, a autonomia e preeminência política da camada dos intelectuais do Império, principalmente em seus extratos políticos superiores, deve ser sempre entendida em sua organicidade em relação à classe senhorial. Esse intelectuais de classe dirigiram, ampliaram 0 alcance e universalizaram, tornando-os nacionais, os interesses da classe senhorial. Na verdade, esses interesses não existiram mesmo no plano geral independente da ação desses intelectuais. Essa ação, por sua vez, só pode ser plenamente entendida em seu alcance e significado históricos se remetida à formação, manutenção e expansão do poder da classe senhorial, em relação aos escravos e aos outros grupos sociais da sociedade imperial, tornados, nesse processo, subalternos.

Nesse ponto, é fundamental entender o papel político de longa duração que os escravos desempenharam em todo o processo. Sua ação social, pelo menos até a década de 1880 , teve como marca predominante a dispersão e a fragmentação. Assim, é correta a caracterização geral que a historiografia atual faz - consciente ou inconscientemente - das lutas escravas como resistência. Com exceção do conjunto de revoltas escravas que eclodiram na Bahia do princípio do século XIX até a culminação do Levante dos Malês, em 1835, em Salvador, revoltas escravas nunca adquiriram caráter geral e ameaçaram a ordem política do Império. Mesmo no caso da Bahia, a dimensão da revolta não ultrapassou os limites da província. Não obstante, a política do Império não pode ser entendida sem a remissão constante à presença dos escravos na vida social e política. Na vida social, no que diz respeito à administração cotidiana da ordem escravista privada e local. Crimes, fugas, desobediências, estavam lá o tempo todo para lembrar os senhores e as autoridades locais quem era seu "inimigo inconciliável", como os designou, em 1854, uma comissão de fazendeiros de Vassouras, em cujo objetivo era monitorá-los. ${ }^{80}$

No plano político mais geral, a presença de uma grande massa de escravos em todos os cantos e entre todas as camadas sociais do Império 
81

0 grande temor causado entre senhores e autoridades pela Revolta dos Malês, em 1835, em Salvador, deveu-se a que a rebelião, ou o plano de rebelião, ao aglutinar africanos, em sua maioria muçulmanos, escravizados e livres, rompia com esse padrão. Sobre a revolta ver o clássico de REIS, João José Reis. Rebelião escrava no Brasil. São Paulo: Companhia das Letras, 2003. teve efeitos variados ao longo do tempo e do espaço, dependendo de sua articulação com o conjunto de questões políticas que pautavam a agenda nacional e internacional em diferentes momentos. Uma coisa é certa, a escravidão e a presença ativa ou potencial dos escravos representaram um poderoso fator de inibição para uma radicalização democrática dos limites sociais e institucionais do liberalismo. Um non plus ultra que estreitou as bases sociais potenciais das correntes políticas liberais e facilitou a formação de um consenso conservador e socialmente restritivo, produzindo uma espécie de limite social da vida política.

$\mathrm{Na}$ Europa, inicialmente, esse limite social da vida política foi representado pelos efeitos e pela experiência adquirida com a Revolução Francesa e as guerras napoleônicas, que contribuíram fortemente para pautar a política do continente na primeira metade do XIX. A partir das revoluções de 1830 e, principalmente, 1848, esse papel coube à constante ameaça das classes perigosas. Nas décadas de 1880 e 1890, no entanto, essa ameaça, se não deixara de existir, transformara-se, na maior parte dos paises, em presença política institucional canalizada por partidos de base operária e/ ou trabalhadora, democráticos, em Estados liberais mais ou menos democratizados pelo alargamento e universalização do sufrágio masculino.

Nas sociedades americanas da segunda escravidão, o limite social da vida política foi muito mais demarcado e inelástico. Inicialmente, ele foi representado pelos efeitos e pela experiência adquirida com a Revolução Haitiana. Prevenir e evitar novas revoluções escravas foram preocupações constantes em todas as sociedades que possuíam escravos. Naquelas em que a escravidão, no entanto, era a base do desenvolvimento econômico e do poder político e social, essas preocupações tiveram que conviver com a expansão da própria escravidão. As soluções encontradas para lidar com essa situação variaram. Em Cuba, a manutenção da escravidão acabou reforçando os laços coloniais. No Sul dos Estados Unidos, mecanismos legais restringiram a escravidão ao espaço claramente delimitado da não-cidadania. No Império do Brasil, constitui-se a única classe escravista que enfeixou, completamente em suas mãos, o poder econômico e o poder político.

No Império, o tráfico internacional, ao despejar, todos os anos, até 1850, carradas de africanos novos no mercado e, assim, tornar a compra de escravos - bem como a compra da própria alforria entre os cativos - acessivel, na maioria das vezes, alimentou solidariedades sociais escravistas. ${ }^{81}$ Dessa forma, paradoxalmente, uma certa democratização da escravidão, por assim dizer, facilitou a construção de poderosas barreiras contra a democratização política. Somente quando as bases sociais da escravidão se estreitaram, ali por volta de meados da década de 1860 e, com mais intensidade e de forma efetiva, a partir da metade dos anos de 1870, começou a se erguer o movimento democrático que culminaria no abolicionismo, na destruição da escravidão e na derrubada do Império. 